\title{
COCKTAILS AND PUBLIC DIPLOMACY
}

I doubt if there is anyone in the United States who is so well acquainted with the people of Viet-Nam. These are very strong statements, but Dr. Janse is an unusual person, and I imagine that you know how few people there are who know anything in terms of scientific detail about Viet-Nam. [...] In terms of knowledge and experience, Dr. Janse is, I believe, beyond doubt the top man in the United States for a [visiting] lectureship in art and archaeology in Viet-Nam. But over and above these qualifications, I think there are other reasons why he should be selected. His appreciation of the people and their culture is of a high order. ${ }^{1025}$

The end of Olov Janse's professional life coincided with a period of great political turmoil in the United States, and in the world at large. In the decades following the Second World War, characterized by the political tensions of the Cold War, the self-image of the United States as the essentially good guy who could never fight a bad war or represent the wrong cause, ${ }^{1026}$ would be tested and contested, not least in the events following

1025. Letter from J. O. Brew, Director of the Peabody Museum at Harvard, to Miss Sylvia Miller, Conference Board of Associated Research Councils, Washington, DC, 16 November 1957. NAA: Janse 2001-29.

1026. Phrasing borrowed from interview with the journalist Neil Sheehan in part 2 of The Vietnam War, a television documentary series written by Geoffrey C. Ward, directed by Ken Burns and Lynn Novick, 2017. The overall description of the situation in the Unites States and its foreign policy relating to Southeast Asia during the Cold War refers to Logevall 2012 and Tønnesson 2010. 
the breakup of Indochina that eventually led to the Vietnam War. ${ }^{1027}$ Olov Janse's name has barely been mentioned in the history of US politics and diplomacy leading to the Vietnam War. In the 1950 s and the first couple of years of the 1960s, when Janse was the most active in the relations between the United States and Vietnam, nothing seemed to indicate that Vietnam less than a decade later would become the place where the contained fears and stubborn polarized positioning of Cold War politics would be released and played out in brutal reality. Everyone in Washington was focusing on the Soviet Union, and Janse was no exception.

In hindsight, however, we can see that he was right at the centre of some of the most important institutions and events of that time. At a time when, incredible as it may sound, many people in the United States did not even know the location of Vietnam, let alone anything about its culture and political history, Olov Janse was known as one of the United States' main experts on Indochina's history and culture. ${ }^{1028}$ From a position that has been nearly invisible to historians focusing on the archives of politicians, diplomats, and high-profile units of official administration, he mediated between key actors, shared knowledge, and communicated narratives that were used for purposes of public diplomacy. During the 1950 s and early 1960 s he worked at the US Department of State and the Smithsonian Institution, made two long journeys to Europe on research grants from the State Department, and together with Renée he mingled at cocktail parties with the political and cultural elite of Washington, DC. In 1958-59 he spent six months as a visiting professor and heritage adviser in South Vietnam and Korea, on a public diplomacy mission supported by the Smith-Mundt Act. A year later, he had a key role in setting up The Art and Archaeology of Viet Nam, a travelling exhibition shown in both Vietnam and the United States. It has been described as "one of the most important episodes in [President Ngo Dinh] Diem's plan to win American public support for his regime". ${ }^{1029}$ Yet at this time, everyone, Janse included, was blinded by the threat from the Soviet Union and the fear of communism spreading across Asia. Few if any took Ho Chi Minh

1027. What is most known in the Western world as the Vietnam War was also fought in the neighbouring countries, most notably in Laos, and in Southeast Asia it is widely known as The American War.

1028. NAA: Janse 2001-29; Solheim 1984-85:10.

1029. Masur 2004:170. 
and the Viet Minh seriously as an intelligent force with the strategic capacity to defeat the United States and its allies.

\section{$1947-1953$}

Olov Janse returned from UNE S CO in Paris in July 1947 determined to settle for good in the United States. He and Ronny became US citizens on 7 September 1948, and at the same time Ronny changed her first name to Renée. ${ }^{1030}$ She worked at the Library of Congress, in the Descriptive Cataloging Division. She was later promoted to other departments within the library, where she stayed employed until her retirement in 1971. Olov's employment was less steady. During the first years back in the United States, he had assignments with the Department of State and the Smithsonian Institution in Washington, DC. ${ }^{1031}$ At the Department of State he worked in the Foreign Service Institute, where experts offered instruction and training for diplomats and other members of the Foreign Service. At the Smithsonian Institution he investigated the possibilities to establish "an international body of archaeologists and a permanent bureau for archaeology". ${ }^{1032}$

Otherwise this was a period of low professional activity for Olov Janse. Correspondence with his old friends Ture and Birger Nerman in Stockholm shows that he spent much time and effort working on his philatelic collections, exchanging stamps with Ture and his son Anders. He and Ronny built a summer cottage at Cove Point near Chesapeake Bay in Maryland, and spent almost every long weekend there. In letters he compares their house with Ture's summer house on Blidö in the Stockholm archipelago, and describes how the mild climate in Maryland -"on the same parallel as Venice"- allowed them to grow figs and peaches, and swim in the sea from early spring to late autumn. Their primary focus was on putting down roots in their new country.

1030. Luther H. Evans, Library of Congress, Information Bulletin 21-27 September 1948,4 .

1031. We have not found any formal documentation of his employment in this period, so this is concluded from comments in letters and press records (e.g. Shumaker 1953).

1032. The initiative came officially from the successor in Janse's position at UNE SCO, J.J. Mayoux, but appears also to have been in Janse's own interest. The plans were never realized, and the project is only mentioned in a letter to Birger Nerman (with typed memorandum in English attached). Letter from Janse to Nerman, 29 September 1947. Riksarkivet. Kartong 5. Korrespondens Brev 1947-1950. 
Olov's main professional focus during these years, in the late 1940s and early 1950s, was on completing the archaeological reports from their Indochina expeditions, the first volume of which was published in 1947. ${ }^{1033}$ A couple of years later he received a travel grant from the State Department to spend eight months in Europe to complete the second and third report volumes. Renée came along with him. In April 1946 she had been appointed to a position at the Library of Congress as a cataloguer of Slavic material, particularly Russian publications. In the Library of Congress's Information Bulletin she was praised in these terms: "Persons possessing her special talent are hard to find, and we were delighted that Mrs. Janse was available for this urgent program." ${ }^{1034}$ The Library of Congress had sent her to study Slavic literature in European libraries. She visited libraries in Paris, Rome, Naples, Stockholm, Uppsala, and Helsin$\mathrm{ki}$, and on her return she wrote a report for the Library of Congress. ${ }^{1035}$ Olov Janse filmed parts of their journey and bought films produced for the tourist market. ${ }^{1036}$

On 29 March 1950 they boarded the luxury art deco ocean liner S S Ille de France in New York, bound for Le Havre in France. On what was Renée's first visit to Europe after the war, they spent a month together in Paris before they travelled by bus to Italy and by train to Sweden, where they stayed a couple of weeks seeing family and old friends. When Renée had to return to tend to her work at the Library of Congress, Olov spent several busy months in Paris working on his third report volume. ${ }^{1037}$

Soon after he had returned to the United States and joined Renée in Washington, his friend and mentor René Grousset came to visit. It was now late autumn 1950. Olov and Renée arranged for Grousset to give a lecture at the prestigious art institution Dumbarton Oaks, and hosted a reception for him in their home, where French cultural and diplomatic dignitaries such as Jean Marx and Alexis Léger (aka Saint-John Perse,

1033. Janse 1947 .

1034. Library of Congress, Information Bulletin 18-24 February 1947, 4.

1035. Office of the Secretary, The Librarian Director, Reference Department. Mrs. Renée S. Janse, Bibliographer Air Information Section, Air Studies Division. Travel Report and Survey of Slavic Collections abroad April 10-June 17, 1950; Authority No. $50-277$. Library of Congress.

1036. Swedish Television Archive. (C) SVT Arkiv.

1037. Letter from O. Janse to T. Nerman, 21 June 1950. Arbetarrörelsens arkiv och bibliotek. Ture Nerman 3.1.46. 
Nobel Laureate in literature 1960) mingled with representatives from several of Washington's embassies. ${ }^{1038}$

The second volume of Janse's report from Indochina was published shortly after Grousset's visit. ${ }^{1039}$ It received a glowing review by Paul Mus, his former colleague at the EFEO in Hanoi, in the Journal of the American Oriental Society. ${ }^{1040}$ Mus was not in agreement with Janse's conclusions on the Mediterranean connections of some of the most prolific artefacts, including the kneeling figurine from Lach-truong. ${ }^{1041}$ Apart from that, the review is outstandingly positive. With words such as "monumental" and "brilliant", Mus praises Janse's results and his stylish and comprehensive presentation. He is particularly impressed by the elaborate index, which, Mus wrote, by the use of adjectives not only helped the description but also the interpretation of objects and style elements. Once again Janse's French connections were reinforced and reinvigorated.

This was, however, a period of growing tension in US foreign politics. After the immediate shock of the Second World War and the dramatic effects of the Marshall Plan in the years following, came the fear-based passive aggression of the Cold War. Harry S. Truman was President and his Secretary of State was Dean Acheson. ${ }^{1042}$ Acheson has been described as "a central player, arguably the central player, in the drama of the late 1940 s and early 1950 s that saw the United States become a global hegemon, the self-appointed defender of Western civilization". ${ }^{1043}$ The Soviet Union's nuclear bomb test in Kazakhstan in August 1949 and Mao Zedong's proclamation of the People's Republic of China in October the same year saw Truman and Acheson instigate a new Top Secret National Security Council Report. This report - N S C 68 (signed in April 1950) ${ }^{1044}$ - revised the foreign policy of the United States in response to what was perceived as a threat of unfathomable proportions:

1038. Letter from O. Janse to T. Nerman, 3 January 1951. Arbetarrörelsens arkiv och bibliotek. Ture Nerman 3.1.46.

1039. Janse 1951.

1040. Mus 1952.

1041. See the chapter "Euphoria".

1042. Logevall 2012:217-220; Acheson 1969.

1043. Logevall 2012:217, emphasis in the original.

1044. "A Report to the National Security Council - NSC 68", 12 April 1950. President's Secretary's File, Truman Papers. 
The issues that face us are momentous, involving the fulfilment or destruction not only of this Republic but of civilization itself. They are issues which will not await our deliberations. With conscience and resolution this Government and the people it represents must now take new and fateful decisions. ${ }^{1045}$

As indicated here by the NSC 68 report, the threat from the Soviet Union and the spread of communism in Asia manifested by Mao's revolution in China overshadowed, or tinted, all judgements and decisions made at the US State Department at this time. NATO was formed in direct response to the situation described in the NSC 68 report. And when the Korean War broke out in June 1950 with the invasion of the Republic of Korea by the communist Korean People's Army, (supported by the Soviet Union and China), the United States chose to get involved in the hostilities and support the Republic of Korea via the United Nations, which in turn was strongly influenced by the United States and President Truman.

In Indochina, as in Korea, there was an ongoing struggle for political control after the Second World War. The Viet Minh led by Ho Chi Minh was the largest and most successful of several movements for independence. The Viet Minh was a communist organization, but when he declared the establishment of the Democratic Republic of Vietnam in Hanoi in September 1945, Ho begun with a Vietnamese translation of the words of Thomas Jefferson in the United States Declaration of Independence:

[We believe that ] all men are created equal, [that] they are endowed by their Creator with certain unalienable Rights, and among these are Life, Liberty and the pursuit of Happiness.

Having been supported by the OSS during the Second World War, Ho Chi Minh wrote a telegram to President Truman in February 1946 requesting further support from the United States in their struggle for independence. ${ }^{1046}$ The United States, however, did not intend to support a communist independence movement - communism should be contained, not supported. Moreover, the French did not intend to let go of what had been the most esteemed of all their colonies - la perle of the French em-

1045. "A Report to the National Security Council - NSC 68", 12 April 1950. President's Secretary's File, Truman Papers, p. 4 (Corrected).

1046. Logevall 2012:78. 
pire. ${ }^{1047}$ French forces had already taken back Saigon in the south (while the Viet Minh controlled the northern parts of the country) already in the autumn 1945, and several years of guerrilla warfare followed around Saigon. The French scholar Paul Mus, who had grown up in Indochina, who wrote the review of Janse's second report, and who would later be known as one of the world's most prominent scholars in Vietnamese studies, ${ }^{1048}$ met Ho Chi Minh in the jungles of northern Vietnam to present a French proposal to settle the war through diplomatic agreement. The meeting was in vain, and the fighting continued between the French forces and the Viet Minh. When Ho Chi Minh gained recognition for his government from China and the Soviet Union in 1950, the conflict escalated into a conventional war between a new French-supported alternative government, the State of Vietnam, in the south, and Ho's Democratic Republic of Vietnam in the north. When France sought support from the United States to suppress the communist upsurge, President Truman and Secretary of State Acheson hesitated. They were caught between two key principles: their policy of containment of communism in Asia, and the strong principle to defend the liberty of postcolonial nations that Truman had inherited from his predecessor Franklin D. Roosevelt. In the end, the fear of communism won (also in keeping with the NSC 68 report), and the US government eventually decided to support the French with weaponry and military observers.

At this critical time in the political relationship between the United States and Vietnam, Olov Janse - described as one of few people in the United States with profound knowledge and long-term experience of Indochina ${ }^{1049}$ - worked at the State Department on issues concerning Scandinavia. At the Foreign Service Institute, where experts offered instruction and training for new members of the Foreign Service, he was an expert in the Swedish language. He wrote a dictionary of Swedish for everyday use, ${ }^{1050}$ and circulated his friend Ture Nerman's anti-Soviet journal Trots Allt! among his Swedish-speaking colleagues at the State

1047. A detailed account of the complicated political turns in and around Indochina after the Second World War is found in Logevall 2012: chapters 3-15.

1048. Chandler 2009, Logevall 2012:189-195.

1049. Letter from J. O. Brew, Director of the Peabody Museum at Harvard, to Miss Sylvia Miller, Conference Board of Associated Research Councils, Washington, D.C., 16 November 1957. NAA: Janse 2001-29.

1050. Janse 1955; see also Letter from Olov Janse to Ture Nerman, 10 September 1952. Arbetarrörelsens arkiv och bibliotek. Ture Nerman 3.1.46. 
Department. ${ }^{1051}$ Like most of his colleagues, he was much occupied with the developments in and around the Soviet Union. ${ }^{1052}$ In the evenings, he relaxed by playing solitaire and attending to his stamp collections "to forget about Hitler and his ghosts, Gulag and ugly Josef with the pipe". ${ }^{1053}$ Stamp collection was one of his key interests at this time, and he appears to have had broader ambitions with it than just leisure. He wrote to Ture Nerman:

What do you think of the latest NATO stamps? Why does the Swedish postal service always look backwards never forward when it comes to what I would like to call enlightenment stamps. Here, the stamps are considered quite important as they can serve the enlightenment in the world and the Congress has quite a lot to say about new stamps. Why not bring the matter up for debate in Stockholm? ${ }^{1054}$

He was clearly seduced by the aims of US public diplomacy, and thought it could be a good idea for the Swedish government too, to use stamps to "serve the enlightenment in the world". ${ }^{1055}$ In 1952 he formed a philatelic club at the US State Department. ${ }^{1056}$

He celebrated his sixtieth birthday in August 1952, hoping that the eloquent and progressive Democratic candidate Adlai Stevenson would win the presidential election. A couple of months later, however, the Republican candidate Dwight Eisenhower was elected new President of the United States.

1051. Letter from O. Janse to T. Nerman, 9 October 1951. Arbetarrörelsens arkiv och bibliotek. Ture Nerman 3.1.46.

1052. Letters between O. Janse and T. Nerman, 1947-1952. Arbetarrörelsens arkiv och bibliotek. Ture Nerman 3.1.46.

1053. Letter from O. Janse to T. Nerman, 29 July 1950. Arbetarrörelsens arkiv och bibliotek. Ture Nerman 3.1.46.

1054. Letter from O. Janse to T. Nerman, 30 April 1952. Arbetarrörelsens arkiv och bibliotek. Ture Nerman 3.1.46. In the Swedish original: "Vad tycker du om de senaste Nato-frimärkena? Varför blickar svenska postverket bara bakåt aldrig framåt när det gäller vad jag skulle vilja kalla upplysningsfrimärken. Här anses frimärkena ganska viktiga då de kan tjäna upplysningen i världen och Congressen har rätt mycket att säga till om när det gäller nya frimärken. Varför inte ta upp saken till debatt i Stockholm?”

1055. Letter from O. Janse to T. Nerman, 30 April 1952. Arbetarrörelsens arkiv och bibliotek. Ture Nerman 3.1.46.

1056. Letter from O. Janse to T. Nerman, 17 November 1952. Arbetarrörelsens arkiv och bibliotek. Ture Nerman 3.1.46. 
The death of Josef Stalin in March 1953 brought a sense of relief to the US Department of State. In his election campaign a year earlier, President Eisenhower had promised to end the Korean War, and after hints that the United States might make use of its nuclear arsenal, the parties declared an armistice in July 1953. The truce in Korea in combination with Stalin's death seemed to indicate a release of Cold War tensions and sparked hopes of the possibility to contain communism in Asia. Yet Eisenhower had named John Foster Dulles his Secretary of State. Both Eisenhower and Dulles were staunch anti-communists, and Dulles in particular was known for his stern personality and straightforward decision-making: "He had it all in his head. He did not need the ambassadorial analyses and the studies of the policy planning staff and the host of departmental experts. He had a big yellow pad at his bedside and he jotted down thoughts as they occurred to him." ${ }^{1057}$ Dulles wanted a stronger US foreign policy with more "heart", and maintained that the policy of "containment" (of communism) ought to be replaced by a policy of "liberation". ${ }^{1058}$ True to his intentions, in 1954 John Foster Dulles was the prime mover in the creation of SEATO (the Southeast Asian equivalent of NATO) to strike down any attempts at further expansion of communism in Asia.

Meanwhile, in Indochina the war escalated over the first years of the 1950 s. It reached a crescendo in the battle of Dien Bien Phu in the spring 1954, where the Viet Minh (supported by China and the Soviet Union) had a devastating victory over the French forces (supported by US funding and allied armies from the neighbouring countries) at the cost of thousands of lives on both sides. The battle of Dien Bien Phu began during the Geneva Conference (April-July 1954), a meeting that was intended to settle the conflicts in Korea and Indochina and reach a diplomatic agreement on the post-colonial partition of Indochina. As a result of France's defeat at Dien Bien Phu and the diplomatic efforts at the Geneva Conference, the former French Indochina was divided in 1954 into the independent Kingdom of Laos, the Kingdom of Cambodia, the Democratic Republic of Vietnam (often referred to as North Vietnam), and the State of Vietnam (South Vietnam). The division of Vietnam

1057. The New York Times, 25 May 1959: "Dulles Formulated and Conducted U.S. Foreign Policy for More Than Six Years".

1058. Ibid. 
at the 17 th parallel was meant to be a temporary solution, the ultimate intention being to unite North and South Vietnam in one nation state. The north, with the capital in Hanoi, was ruled by Ho Chi Minh and the Viet Minh. The south, centred around its capital in Saigon, was ruled by Bao Dai, the Francophile former emperor of the Nguyen dynasty, and his Prime Minister Ngo Dinh Diem.

Ngo Dinh Diem was, however, not pleased with the deal. Only a year after the settlement of the Geneva Accords, he pursued a public campaign against the emperor, organized and won an election, after which he deposed Bao Dai and declared the Republic of Vietnam with himself as President. ${ }^{1059}$ Ngo Dinh Diem was of a Vietnamese Catholic family, which had been persecuted and almost extinguished in his father's generation during an anti-Catholic riot led by Buddhist monks. He received both Confucian and French education in his hometown Hué, before he followed his brother (who later became the highest ranking Catholic bishop in Vietnam) to stay in a monastery, where he swore celibacy. From there he built a career as a mandarin (a learned bureaucrat) in the native administration of Indochina. Hence Ngo Dinh Diem, often referred to by his given name Diem, was a Catholic single man who lived for his work and resented both Buddhists and the French colonizers whom he regarded as wrongful occupants of his native land. After the end of the Second World War, Diem had represented a Third Force movement for independence that united non-communist and anti-French nationalists. ${ }^{1060}$ Like Ho Chi Minh, Diem sought support from the United States already in the early 1950 s, and eventually gained the confidence of many high-ranking US officials, including Justice William O. Douglas, the former OSS director Bill Donovan, and then-senator John F. Kennedy.

On "Independence Day", 4 July 1954, Olov Janse wrote one of very few direct observations on the political situation in Indochina, to his friend Ture Nerman. In what we can assume is a heartfelt comment, unlike press interviews or articles that are of a more careful and strategic character, he writes:

It is looking troublesome in the world at the moment. Will be interesting to see the outcomes in Geneva. France is losing its

1059. Chapman 2013: chapter 6.

1060. Chapman 2013. 
colonies in Africa too. Shame though that they will not be free, but end up under the Russians. ${ }^{1061}$

The short comment reflects what appears to have been a broader conceptualization of the Viet Minh among the US administration, not as a force of its own, but as a Russian marionette. On a more personal level, we also see in Janse's words a sense of sadness or disillusionment about the political chess game that was using the people of Indochina as pawns.

A couple of months earlier, in March 1954, just before the battle of Dien Bien Phu, Olov Janse was called to the Swedish Embassy in Washington, DC, where he was awarded the Order of the Polar Star (Swe: Nordstjärneorden) for "civic merits, for devotion to duty, for science, literary, learned and useful works and for new and beneficial institutions". He wrote later to Birger Nerman that he was "of course happy to have received it, but would probably never wear it". He wrote also that he was getting tired of office work and longed to go back to his archaeological research. ${ }^{1062}$ He was saddened by the deaths of several of his old friends and family in Europe: René Grousset and David David-Weill died in 1952, the Norwegian archaeologist Haakon Shetelig in 1955 , his uncle Gustaf Janse in 1956, and C.T. Loo and his uncle Otto Janse, with whom he was very close, in 1957. Both he and Renée suffered from persistent flus and pneumonia. Renée needed treatment for arthritis, and their friends in Sweden were often unwell. In his letters to Ture and Birger Nerman, Olov offers to include American "wonderdrugs" for all their problems and diseases in the packages with coffee and nylon tights that they regularly dispatched. The long weekends in the summer cottage with Scandinavian-style cultivation and cold baths in Chesapeake Bay were now replaced by frequent recreational trips to Fort Lauderdale in "paradisal Florida", "where fresh trade winds now make the climate ideal and we for a moment can steer our minds away from world politics". ${ }^{1063}$

1061. Letter from O. Janse to T. Nerman, 4 July 1954. Arbetarrörelsens arkiv och bibliotek. Ture Nerman 3.1.46. In the Swedish original: "Det ser otrevligt ut i världen just nu. Skall bli intressant få se hur det går i Genève. Frankrike håller nu på att mista också sina kolonier i Afrika. Synd bara att de inte blir fria utan kommer under Ryssarna." 1062. Letter from O. Janse to B. Nerman, 9 March 1954. Riksarkivet. Kartong 6. Korrespondens Brev 1950-1956.

1063. In the years 1952-1960 they visited Florida to rest and for recreation almost every year. (E.g. letters from O. Janse to T. Nerman, 15 September 1953 and 4 July 1953. Arbetarrörelsens arkiv och bibliotek. Ture Nerman 3.1.46.) 
The years between 1952 and 1957 were also an increasingly busy time for Olov Janse. His letters abound with references to stress and much partying (Swe: mycket fästande [sic]), and he no longer had time to tend to his stamp collection. The growing political interest in Vietnam had led to an increasing visibility of Southeast Asia in popular media in the United States, and Janse saw an opportunity to capitalize on the attention by writing a popular account of his experiences in Indochina. It would have an emphasis on "the human interest" and make the most out of his own experiences: "I would think that few Europeans have been so much in touch with the so-called broader strata out there, and since Indochina is now in focus for the daily news it might be time to have the manuscript printed [...]." ${ }^{1064} \mathrm{He}$ wrote more than ten chapters in English, but never found a publisher in the United States. Instead he wrote a Swedish version, which was published as his memoirs, Ljusmannens gåta, in 1959. ${ }^{1065}$

The focus on Southeast Asia also led to more activity in Washington's diplomatic community. In April 1954, at the time of the Geneva Conference, Olov and Renée attended a reception at the Embassy of Laos to celebrate the golden jubilee of King Sisavang Vong. At the reception they met Vice President Richard Nixon and his wife Pat. Shortly thereafter Janse sent Nixon copies of the first two volumes of his archaeological reports from Indochina and "The Peoples of Indochina" booklet that he had produced earlier for the State Department. Nixon wrote back on 28 April to thank him for the books: "This is just a note to thank you for your letter of April 15 and to tell you how very much Mrs. Nixon and I enjoyed meeting you and Mrs. Janse the other day [...]." ${ }^{1066}$

In early 1955, Olov was contracted to give a new course in Advanced International Studies at Baltimore University (but located in Washington, DC), and in the spring he and Ronny travelled to Europe where Olov lectured in Paris and Oslo. He made preparations for a fourth volume of Archaeological Research in Indochina ${ }^{1067}$ and they spent several weeks on study trips-cum-vacation in Italy and Sweden. On the study trips he vis-

1064. Letter from O. Janse to T. Nerman, 28 July 1953. Arbetarrörelsens arkiv och bibliotek. Ture Nerman 3.1.46. ; Letter from O. Janse to B. Nerman, 9 March 1954. Riksarkivet. Kartong 6. Korrespondens Brev 1950-1956.

1065. Janse 1959.

1066. Letter from R. Nixon to O. Janse, 28 April 1954. NAA: Janse 2001-29.

1067. The volume, on which he worked, according to letters, between 1955 and 1969, was never published. Nor have any manuscripts been found in the archives we have consulted. 


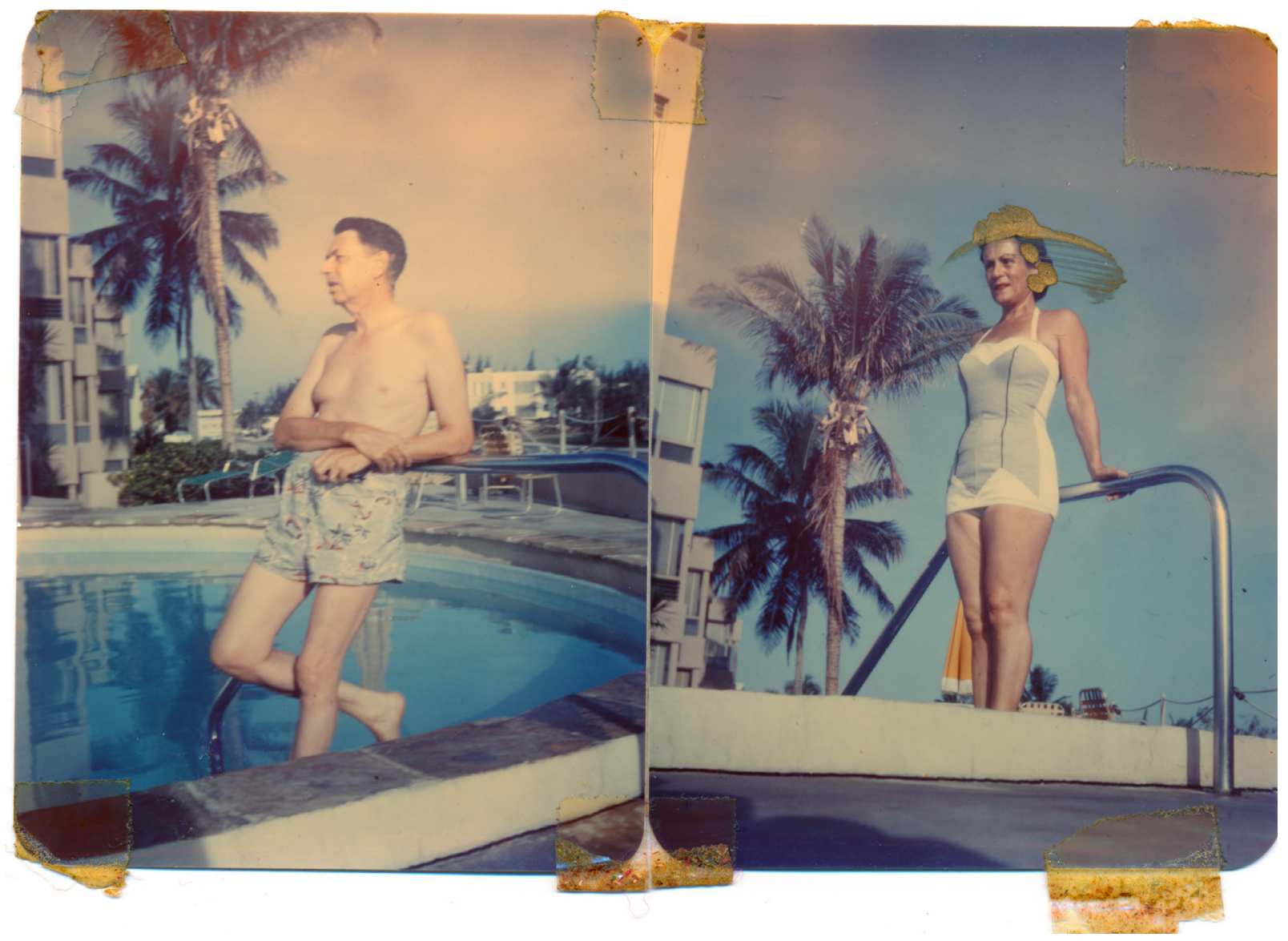

Fig. 75. Holi- ited museums in Rome and Naples, where he found "many new evidences day in Florida, of Hellenistic influence on Southeast Asian art". ${ }^{1068}$ As he picked up his in the 1950 s. archaeological research again, after more than a decade working mainly on bureaucratic tasks, it was the long-distance East-West connections within a template of cultural diffusion from the Mediterranean to the Far East that once again sparked his enthusiasm. In an article written around this time for a Norwegian journal, he writes: "The research of the past decades has, as we know, demonstrated that the peoples of East Asia were affected by cultural impulses from the Western world, already during the Stone Age." Many gaps remain to be filled, he continues, particularly in the southern Chinese cultures which are distinctive, and which he had investigated during his three expeditions. He also mentions some recent

1068. Postcard from O. Janse to B. Nerman, 15 July 1955. Riksarkivet. Kartong 6. Korrespondens Brev 1950-1956. 
finds at Oc Eo, an ancient trading site in the Mekong Delta, where there is proof of trade contacts with the Roman Empire, and he emphasizes that "it is necessary to recall the influence of the Hellenistic culture in India after the victory of Alexander the Great in the fourth century BC". ${ }^{1069}$ Seduced by his own master narrative of cultural diffusion from West to East, he let it serve as the template for all material he had encountered at his excavations two decades earlier. Examples of rich and complex cultures where Mediterranean influences could not so easily be argued for (such as the Dong Son kettledrums and the ceramic kilns at Tam-thô) were completely disregarded or downplayed in his presentations at this time. With the narrative he maintained, he once again reinforced and gave scientific legitimacy to the French colonial image of Indochina as a grateful receiver of cultural impulses from the Mediterranean world, from the Stone Age to historic times.

In 1957, things started to move faster. The Soviet Union, then led by Nikita Khrushchev, demonstrated the success of its space programme by launching two Sputnik satellites into orbit. In Vietnam, President Ngo Dinh Diem received increasing support from the United States, which took on the responsibility to "help" Diem turn South Vietnam into a liberal Western-style democracy, and defeat Ho Chi Minh to unite the country once again. Secretary of State John Foster Dulles had shocked the readers of Life Magazine in January 1956, when in an interview he commented on the situation in Vietnam with alarming arrogance, and claimed that the United States was "on a brink of a War". It became clear that there was a very real risk that the US policy of containment of communism would be replaced by a policy of aggression. ${ }^{1070}$

At this time, Olov Janse was helping to organize a travelling exhibition of Vietnamese art and archaeology, in a collaboration between Diem's

1069. Janse 1958a; in the Swedish original: "De senaste decenniernas forskning har, som bekant, visat att Östasiens folk redan under stenåldern påverkats av kulturimpulser, vilka utgått från Västerlandet. [...] Många luckor återstår emellertid att fylla. Det gäller främst det sydkinesiska området, som i flera avseenden visar en speciell kulturprägel. [...] [Det] är utanför det egentliga Kina, hos dess södra granne (nuvarande Viêt Nam), som vi i senare år, genom systematiska utgrävningar erhållit en bättre kännedom om själva den sydkinesiska särkulturen [...] Härvid är det emellertid nödvändigt att erinra om det inflytande, den hellenistiska kulturen kom att utöva i Indien efter Alexander den Stores segertåg på trehundratalet f. Kr.”

1070. Radio programme with analyses of Dulles's interview in: http://pastdaily. com/2013/01/18/looking-at-the-rose-through-world-colored-glasses-january-18-1956/, accessed 28 August 2018. 
government in Saigon and the Smithsonian Institution in Washington. Janse was in fact the prime mover of the exhibition. He first presented the idea in 1954, and throughout the planning phase served as a "special adviser" behind the front organizer Thomas Beggs, Director of the Smithsonian Institution's National Collection of Fine Arts. ${ }^{1071}$ He contributed archaeological knowledge to the physical planning of the exhibition, but he also served as a diplomatic liaison between the Smithsonian Institution and the Vietnamese Embassy, with Ambassador Tran Van Chuong and Second Secretary Du Phuoc Long. ${ }^{1072}$ In the planning phase, the exhibition was presented as a project of public diplomacy that would benefit both the United States and the Republic of Vietnam. In the United States, it would contribute to a much-needed increase in the public knowledge about the culture of Vietnam. From the Vietnamese side, the exhibition was intended to show "the evolution of the Vietnamese people; their race, politics, customs, and art". It was regarded as "a good opportunity" to engage in "political and cultural propaganda for the government and people of Vietnam". ${ }^{1073}$ The historian Matthew Masur has pointed to the intense activity on the part of the Vietnamese in planning this exhibition, and has called it "one of the most important episodes in [President] Diem's plan to win American public support for his regime". ${ }^{1074}$ Masur argues that it has too often been assumed that public diplomacy during the Cold War was essentially driven by the United States to serve US purposes, for the reason that most historians active in this field have only consulted material in English in US archives. ${ }^{1075}$ Masur's own studies of Vietnamese archives have demonstrated the important role played by Vietnamese officials, up to presidential level, in the planning of this particular exhibition.

On 9 May 1957, in the midst of planning for the Smithsonian exhibition, Olov and Renée Janse were invited to a state dinner hosted by Secretary of State John Foster Dulles and his wife Janet. ${ }^{1076}$ There they met President Ngo Dinh Diem, who was on a state visit to the United

1071. Masur 2004; Masur 2009; Letter from O. Janse to B. Nerman, 10 September 1959. Riksarkivet. Kartong 7. Korrespondens Brev 1957-1961.

1072. Masur 2004:171.

1073. Masur 2004:172, and original documents cited there.

1074. Masur 2004:170.

1075. Masur 2009:311.

1076. Invitation card in fig. 76. They probably met Diem also at a reception at the Vietnamese Embassy on 11 May 1957. 
States. The visit took the form of a promotional tour and was largely organized by the lobby group "American Friends of Vietnam", which also supported the plans for the Smithsonian exhibition. Meeting Janse at the dinner party, Diem showed "a serious and scholarly interest in the project". ${ }^{1077}$ Diem's visit to the United States certainly stimulated government interest in the exhibition, and gave an extra boost to the plans. ${ }^{1078}$

In the spring of 1957 , other plans were also taking shape for Janse. The Vietnamese Ambassador to the United States Tran Van Chuong, with whom he collaborated in the exhibition planning, had approached the US Department of State with a proposal to send Janse on a mission to Saigon, to help the National Institute for Historical Research with archaeological excavations, and to give a series of lectures at the University of Saigon about the results from his previous investigations in Indochina - all under the auspices of the Smith-Mundt Act. ${ }^{1079}$ The Smith-Mundt Act was instituted and signed into US law in 1948 "to promote the better understanding of the United States among the peoples of the world and to strengthen cooperative international relations". This goal was going to be achieved by two principal means:

(1) an information service to disseminate abroad information about the United States, its people, and policies promulgated by [official institutions] having to do with matters affecting foreign affairs; (2) an educational exchange service to cooperate with other nations in (a) the interchange of persons, knowledge, and skills; (b) the rendering of technical and other services; (c) the interchange of developments in the field of education, the arts, and sciences. ${ }^{1080}$

In short, the Smith-Mundt Act specified and regulated the US government's involvement in public diplomacy, as a peacetime instrument of foreign policy. It carries some of the legacy of the Office of War Information (OWI) and its secret sister OSS, which were both created for

1077. Mentioned in an article in The Times of Viet Nam, 28 February 1959. NAA: Janse 2001-29.

1078. Masur 2009296.

1079. Official name: The United States Information and Education Exchange Act of 1948.

1080. Public Laws-Ch 36-Jan. 27, 1948, available at US Department of State website: https://www.state.gov/pdcommission/library/177362.htm, accessed 14 January 2018. 
Fig. 76. Invitation card for State Dinner, 9 May 1957.

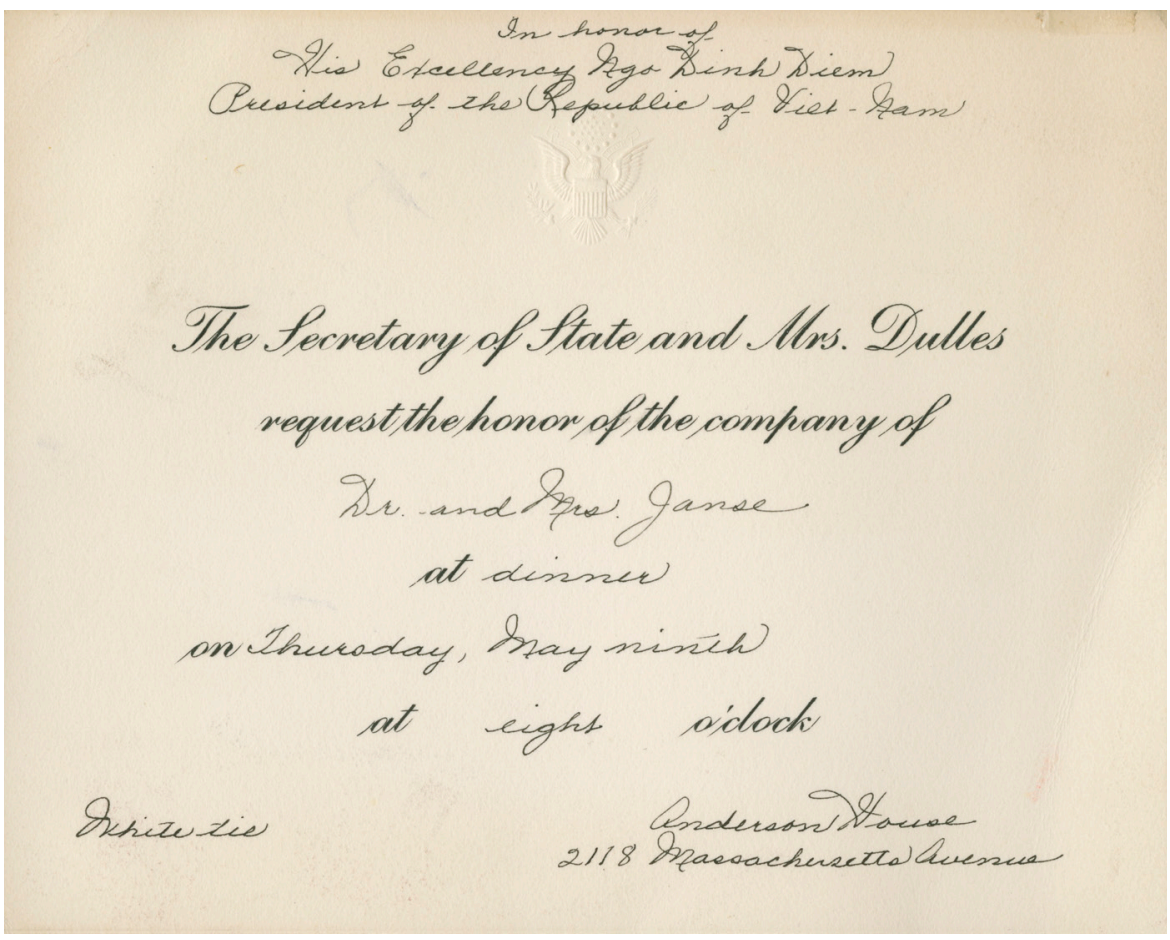

information, intelligence, and propaganda purposes during the Second World War and were dissolved in $1945 .{ }^{1081}$

To support the Smith-Mundt Act, ample funding was allocated by the State Department to enable exchanges and public diplomacy activities. In late April 1957, a couple of weeks before Janse met President Diem at Dulles's dinner party, Nghiem Tham, Director of the Vietnamese Historic Monuments Service in Saigon, wrote a formal letter in French to Manuel Espinosa, Head of the International Exchange Service at the US Department of State, in which he very warmly (Fre: très chaleureusement) recommends Janse for a mission according to the Smith-Mundt Act. Nghiem Tham, who gained his archaeological training in Paris and had been married to a Danish pianist, writes that he has known Janse for a long time, and: "at the moment, Dr Janse is the only scholar [Fre: savant] who could guide us in our archaeological research. Therefore I would be very grateful if you would treat his case with benevolence, and give him

1081. The OW I and the OSS were both dissolved in 1945, but many of their missions and responsibilities were taken over by the US State Department and later the CIA. 
the opportunity to come to Vietnam for a period of 9 months." ${ }^{1082}$ Later in the autumn of 1957 , the Director of the Peabody Museum at Harvard wrote on the same matter to Sylvia Miller, Assistant to the Executive Secretary of the Conference Board of Associated Research Councils:

In the course of this work he has come to know the people well, including not only people of importance in the capital and larger cities, but also the people scattered through the villages and countryside. I doubt if there is anyone in the United States who is so well acquainted with the people of Viet-Nam. These are very strong statements, but Dr. Janse is an unusual person. [...] He will be an extremely sympathetic consultant and advisor to those people in Viet-Nam who are interested in the development of the study of their own prehistory and the presentation of it in museums and schools and colleges. His interest and abilities along these lines seem to me to make his appointment ideal, as I understand the purposes of the Smith-Mundt Act. ${ }^{1083}$

\section{$1958-1963$}

The following March, Olov Janse received a government grant "to participate in an International Educational Exchange program" and "serve as a visiting professor in Viet Nam and other points in surrounding areas as directed by the Department of State". ${ }^{1084}$ It was a generous and prestigious grant, US \$ 915 per month plus travel expenses, and government duty status for six months. Most of the spring and summer was spent on preparations for his journey, and together with Renée he continued to attend dinners and cocktail parties. In August they moved to a more spacious apartment at 4000 Massachusetts Avenue near Georgetown.

On 8 September 1958 he left Renée in Washington, as she could not be absent from her work at the Library of Congress, and travelled via

1082. Letter from Nghiem Tham to Manuel Espinosa, 29 April 1957. NAA: Janse 2001-29.

1083. Letter from J. O. Brew, Director of the Peabody Museum at Harvard, to Miss Sylvia Miller, Conference Board of Associated Research Councils, Washington, DC, 16 November 1957. NAA: Janse 2001-29.

1084. United States Government Grant Authorization (Authorization number 993-8, Obligation Number 2392), 28 March 1958. NAA: Janse 2001-29. 
Brussels, Paris, Athens, New Delhi, Lahore, Taxila and Bangkok, to Saigon, where he arrived on 3 October 1958. In Brussels he visited the modernistic world fair Expo 58, which he found "interesting" which he captured on colour film. Further along the way he studied collections of "Hellenistic" artefacts from the time of Alexander the Great in Taxila. In India, where he stayed more than a week, he was hosted by the National Board of Antiquities and was taken on a guided tour to see the Taj Mahal. Having arrived in Saigon he wrote to Ture Nerman and complained that the journey, although interesting, had also been exhausting. It was the first time that he travelled to Asia by plane, and he explained that he now "had to go to bed when [he] would usually wake up, and vice versa". ${ }^{1086}$

He checked in at the Hotel Majestic in Saigon, and gave his first lecture on Saturday evening, 12 December, to a packed auditorium at the Faculty of Letters at Saigon University. It was the first of three lectures in French, ${ }^{1087}$ all titled "Les origines de la civilization du Viet-Nam" - The origins of Vietnamese civilization. The lecture was chaired by the Minister of Education Tran Huu The, and in the audience were members of the diplomatic community, a delegation from Michigan University, members of Vietnamese and foreign communities, members of the educational corps, and a great number of students. ${ }^{1088}$ The Vietnamese linguist and author Nguyen Dinh Hoa was also there. In his memoirs he recalls:

There was no lack of intellectual excitement in Saigon in those days. Olov Jansé spoke on the origins of the Vietnamese civilization; Father Nguyen Van Thich on Dai-hoc, one of the Four Books of Confucianism; Bui Quang Tung on the uprising of the Trung Sisters; Thai Van Kiem on place names and folklore of South Vietnam; Georges Condominas on Mnong Gar ethnography; Truong Buu Lam on Vietnamese history; Father A. Gélinas on the Chinese classics; Vuong Hong Sen on the classical theatre,

1085. Letters from O. Janse to T. Nerman, 5 August 1958; 16 September 1958. Riksarkivet. Kartong 7. Korrespondens Brev 1957-1961.

1086. Letter from O. Janse to T. Nerman, 3 October 1958. Ibid.

1087. The lectures in French were given on 12, 17, and 19 December 1958.

1088. Vietnam Press Report 13 December 1958: "Conférence du professeur. Janse de l'Université de Harvard sur 'Les origines de la civilisation du Viet-Nam'". NAA: Janse 2001-29. 

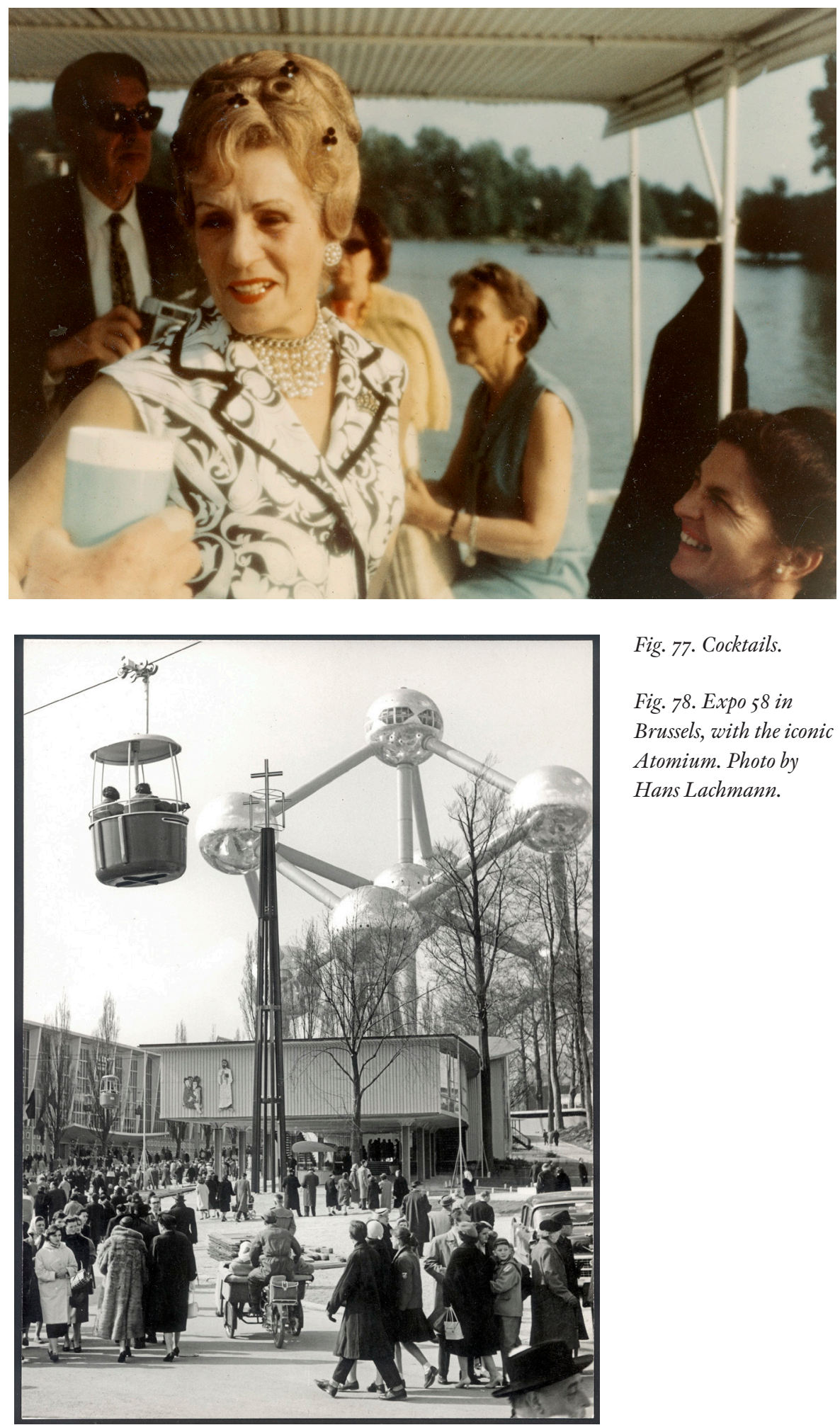

Fig. 77. Cocktails.

Fig. 78. Expo 58 in

Brussels, with the iconic

Atomium. Photo by

Hans Lachmann. 
just to name some of the enlightening presentations that I had the pleasure to attend in 1958 alone. ${ }^{1089}$

In January 1959 Janse continued with a series of three lectures in English in the Auditorium of the Vietnam-America Association. ${ }^{1090}$ The lectures were enthusiastically advertised in the Foreign Service Newsletter, issued by the United States Information Service:
A series of colorful slides will illustrate the lecture. Dr. Janse has many absorbing details to disclose. Plan to be present at one of the finest intellectual treats which Saigon can offer. [...] This is your chance to break away from that television set! ${ }^{1091}$

In his English lectures Janse spoke about his excavations at Dong Son, and of the Dong Son civilization as a mix of Protomalayans, Muong, Chinese, and a cultural element from the Near East or Central Europe - a people with Indo-European language which had invaded China in the eighth century BC, and the frontline troops of which had conquered northern Vietnam. This was a river-valley civilization, he continued, and there are probably many settlements similar to Dong Son yet to be discovered. It is very likely, he said, that the development work on the Mekong that has already begun will uncover other settlements of the same type as Dong Son. The Dong Son finds are remarkable for their outstanding forms and decorative motifs, of which some may explain certain traditions that have remained in Southeast Asia to our days, he concluded. ${ }^{1092}$ The newspaper The Times of Vietnam, which was closely associated with President Diem's regime, reported on the lectures:

Western civilization was brought to this country by an Indo-European type of people who, according to available sources, invaded Western China during the 7 th century before Christ. It is very probable that the vanguard of the invading army actually reached North Viet Nam.

1089. Nguyen Dinh Hoa 1999:138.

1090. The lectures in English were given on Wednesday evenings on 14, 21, and 28 January 1959.

1091. NAA: Janse 2001-29.

1092. Vietnam Press Report, 29 January 1959: "Conférence du Professeur Olov Janse au siège de l'Association Vietnam-Amérique”. NAA: Janse 2001-29. 
This opinion was expressed by Professor Olov Janse Wednesday night at the headquarters of the Vietnamese-American Association. [....] His companion [at the excavations] was Mr Nguyen Xuan Dong, who is presently curator of the Cham Museum at Nha Trang. Together these two men conducted research around several monuments dating back to the beginning of the Christian era and brought to light the famous Dong Son ruins [...]. ${ }^{1093}$

Just like the press reports by the native Indochinese press at the time of his expeditions two decades earlier, and unlike the press in France or the United States that always focused on the kneeling figurine from Lach-truong, the reports in the Vietnamese press had a strong focus on Dong Son. Now, however, much emphasis was on the Western origin of the Vietnamese civilization, even in descriptions of Dong Son, where the original native character had previously been emphasized. All references to French collaboration, which were key during the colonial years, were now replaced by an emphasis on his collaboration with Nguyen Xuan Dong.

Beyond Saigon he lectured in Hué (the town of President Diem's birth), and he also gave a radio interview on 3 March $1959 .{ }^{1094} \mathrm{He}$ ended his stay with a final lecture in French at the Alliance Française in Saigon on 4 March, with the title LeViet-Nam: Carrefour de peuples et de civilisationsVietnam: Crossroads of peoples and civilizations.

Apart from the lectures, most of Janse's activities during his stay in Saigon remain obscure. The excavations mentioned in the planning phase were never realized, and it is unclear how much assistance he offered to the Vietnamese heritage authorities, apart from helping to select artefacts for display in the Smithsonian exhibition. On 25 January he set out on an excursion to find the location of a historic site (the Thuân-Kiêu stronghold) in greater Saigon, together with a group of Vietnamese and international colleagues and diplomats. ${ }^{1095}$ We know also that he visited Angkor Wat during the Christmas break in the company of the French art historian Bernard Philippe Groslier (1926-1986), who had just published two popular history books on Angkor, and was stationed in Siem Reap to

1093. Ibid.

1094. Mentioned in letter from Camille Bergeaud to O. Janse, 4 March 1959. NAA: Janse 2001-29.

1095. The Times of Vietnam, 28 January 1959: "Stronghold built a century ago located by archaeology party". 


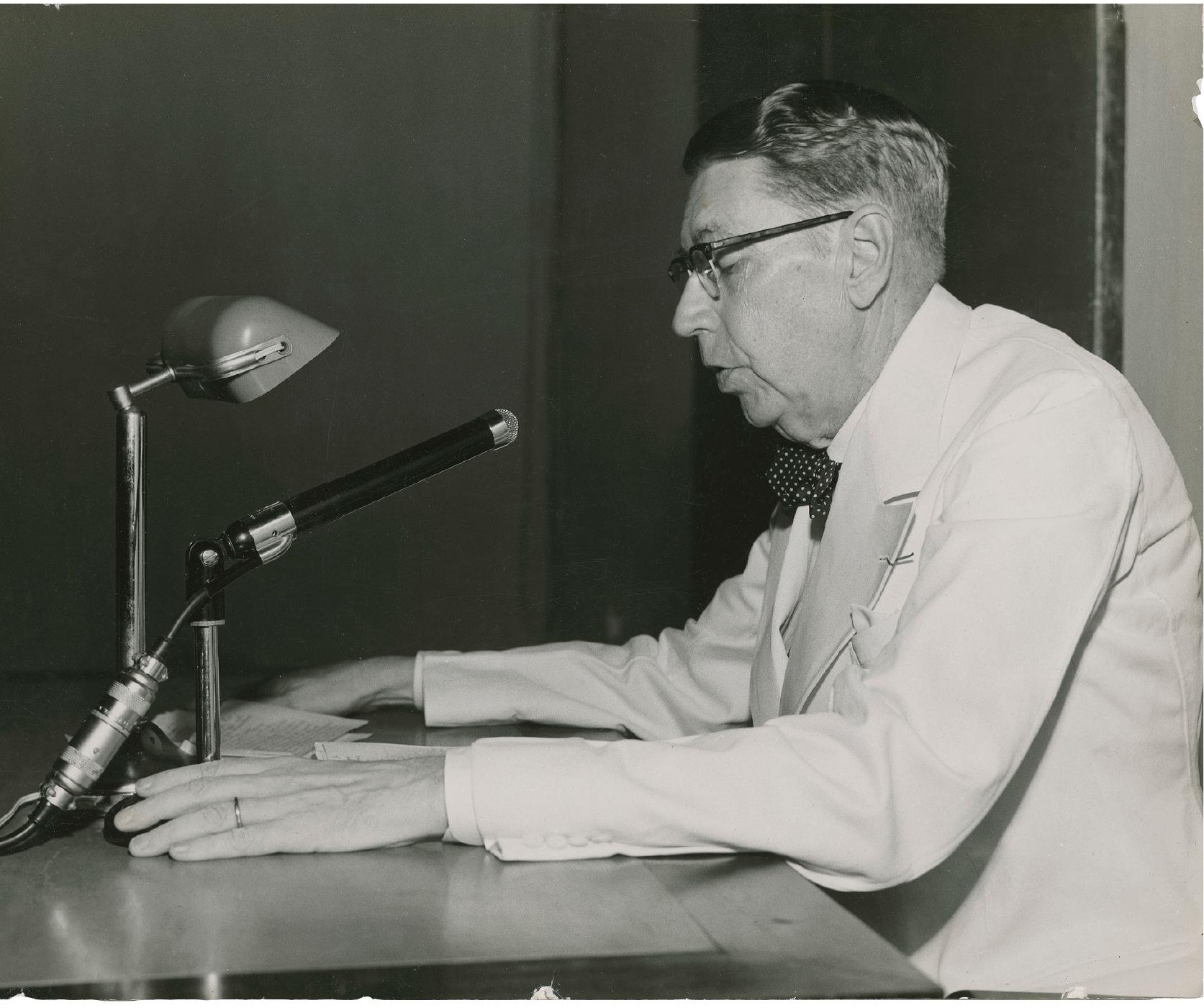

Fig. 79. Olov Janse lectures in Saigon 1959. conduct surveys for the EFEO. As we have mentioned earlier, Groslier would later, in a popular history book on Indochina, describe Olov Janse as the person who introduced order into research on Dong Son. ${ }^{1096}$

During his stay in Saigon Janse also met the young American archaeologist William G. Solheim II (1924-2014), known to most as "Bill", who had contacted Janse already during the Second World War with the intention to join the OSS in Indochina. Now they met in Saigon for the

1096. Groslier 1966:160. 
first time, by chance, and founded a friendship that would last for the rest of Janse's life. Janse introduced Bill Solheim to the idea of starting an archaeological salvage programme around the Mekong river in connection with the Mekong River Project, which under UN auspices surveyed the possibilities to contribute to the development of the countries in mainland Southeast Asia by building dams and other technological developments on the Mekong and its tributaries. ${ }^{1097}$ We shall return to that project and to Bill Solheim in a little while.

In a long feature article in The Times of Vietnam, we get a glimpse of how Janse was perceived during his stay in Saigon:

"I have now retired", says Dr. Janse. But the tall, scholarly man's eyes give out with something that has no hint of retirement when he begins to speak of his work. [...] It is quite evident that his continuing extra-curricular activities actually mean that he is continuing his profession fulltime. [...] The undercurrent of the excitement of discovery comes into his voice - and it is contagious, stirring up images of men in pith-helmets frantically working under the hot sun of the tropical jungles or the deserts to dig up more and yet more of a new find. ${ }^{1098}$

Discussing the finds from his excavations in the 1930s, Janse now suggests "that many of these objects were made in what is now South Viet Nam - possibly in workshops in localities of cosmopolitan character such as Oc Eo, just 25 kilometres from Saigon". ${ }^{1099}$ Oc Eo was a high-profile archaeological site that had been found and excavated in 1940 by Louis Malleret, who later became director of the EFEO. It has been described as the port to the ancient mandala of Funan in the first to sixth centuries $\mathrm{AD}$ and was undoubtedly an ancient trading site of considerable importance, although the existence of Funan as a discernible political entity, as well as its connection with Oc Eo, has since been a matter of contestation. Malleret's investigations at Oc Eo were in fact the first major archaeological research programme focused on southern Vietnam, and investigations

1097. Solheim 2002 ; Jacobs 2000.

1098. The Times of Vietnam, 28 February 1959: "Dr. Olov Janse Completes Archaeological Goodwill Mission - Forthcoming Exhibits, Author's Writings Give World New Insight Into Ancient Viet Nam's Civilization".

1099. Ibid. 
were resumed there at the end of the 1940 s when France was working to restore its colonial institutions in Indochina. ${ }^{100}$ In his interview, however, Olov Janse referred to Oc Eo for confirmation of his own thesis of Western, particularly Hellenistic, influence on the origins of Vietnamese civilization. He ended the interview talking about the new generation of archaeologists, and how impressed he was

by the eagerness of the Vietnamese students to enlarge their knowledge and serve their country. As you know [...] there is a growing consciousness in Viet Nam, among your people and in your Government, of the value of your cultural and national heritage - a heritage of which any country would have a right to be very proud. Those who in the future will be entrusted with the custody of this heritage must be adequately trained. ${ }^{1101}$

He talked about the necessity of high-quality training for Vietnamese archaeologists, and the international importance of a well-functioning heritage administration:

Southeast Asia, and Viet Nam in particular, has been since time immemorial a cross-roads of peoples and civilizations. The importance of archaeology of Viet Nam goes far beyond its national boundaries, and orientalists all over the world are genuinely interested in the matter. If one of the international organizations working on the Mekong Valley Project, for example, should incidentally discover an important site - a strong possibility, by the way - who would be responsible for carrying out systematically conducted excavations? Who would make the final decisions concerning the disposal of the findings? Who would grant the needed funds for publishing the scientific reports? All these questions have scientific implications on an international and political level. ${ }^{1102}$

1100. EFEO 2002:188-189. See also Clémentin-Ojha \& Manguin 2001, pp. 36-40 on the history of EFEO in Hanoi and Saigon 1940-1961.

1101. The Times of Vietnam, 28 February 1959: "Dr. Olov Janse Completes Archaeological Goodwill Mission-Forthcoming Exhibits, Author's Writings Give World New Insight Into Ancient Viet Nam's Civilization.”

1102. Ibid. 
"Oh, yes?" asked the Vietnamese reporter. "Oh, yes", Janse concluded. "When we are planning for the exploration of the past, it is always advisable to look toward the future." ${ }^{1103}$

We see here how the meaning of Janse's archaeological knowledge was transformed for a new context and new purposes. Always attentive to his current social setting, he now gave his results value and meaning in relation to the new Republic of Vietnam, and to his own mission as a representative of the United States. Native archaeologists were important, but not fully accomplished, and therefore needed guidance. However, the patronage was no longer in the form of a French colony, but an international concern. The Vietnamese civilization was no longer based on a prehistory of colonization (as in his 1930s "investigations of the southern expansion of the Chinese Han empire"), but on a cosmopolitan melting pot with foundational influences from Classical Greece. ${ }^{1104}$ The Chinese connection, which used to be key, was downplayed or not mentioned at all. Journalists and editors were also to some extent responsible for the way his knowledge and opinions were featured and presented in newspapers and magazines. Yet we see very similar sentiments expressed in his letters, and his own articles.

There was, however, one complication. Despite his backing from the United States, and his apparently honest and sincere feelings for Vietnam and its people, Olov Janse was a Francophile. In a letter sent just before Janse's departure from Saigon, the French Cultural Consul Camille Bergeaud wrote euphorically how delighted he was to have made Janse's acquaintance, and how much he had enjoyed and benefitted from attending his lectures. Notwithstanding Janse's admirable knowledge, says the Consul, he had just as much appreciated the lectures' spirit of friendly, loyal, and generous cooperation. ${ }^{105}$ In a second letter, Bergeaud specifies that it was particularly the "courtesy and fairness" of Janse's emphasis on the French contribution through the EFEO that he had appreciated the most. ${ }^{1106}$ In an interview given around the same time for the French-Vietnamese newspaper Journal d'Extrême-Orient, Janse "underlines the French

1103. Ibid.

1104. This makes an interesting comparison with the United States, which is often described as a salad bowl, or, indeed, a melting pot of cultures, and draws on plenty of classicistic elements in its manifestations of national heritage (for example in the Capitol and the Lincoln Monument on the Mall in Washington, DC).

1105. Letter from C. Bergeaud to O. Janse, 4 March 1959. NAA: Janse 2001-29.

1106. Letter from C. Bergeaud to O. Janse, 6 March 1959. NAA: Janse 2001-29. 
contribution to archaeological research in Vietnam", and praises the work done in Paris in terms of research and conservation of the finds from his expeditions. "Too much nationalism", he says here, can sometimes hinder collections from being seen and researched in other contexts than their own country can offer. Rather, he advocates acting "in a spirit of mutual interest and above all put scientific interest above human passions". In the long run, he says, "it is obviously in the interest of Vietnam itself to have its cultural heritage better known and more appreciated in the world". For after all, "there are more visitors to the Guimet Museum than to the Saigon Museum". ${ }^{1107}$ Janse's steadfast loyalty to France, and his belief in the French colonial contribution in Indochina as something ultimately beneficial, no doubt complicated his relations with the political leadership of the United States, as well as the Vietnamese independence parties, both north and south.

Janse's activities during his stay in Saigon were regularly reported by the local press, particularly the English-language daily newspaper The Times of Viet Nam. Owned and run by the American couple Gene and Anne Gregory, ${ }^{1108}$ who were close friends with President Diem's sisterin-law, the legendary Madame Nhu, ${ }^{1109}$ The Times of Viet Nam was closely associated with Diem's presidency. Gene and Anne Gregory were well informed of Janse's stay in Saigon and hosted a farewell cocktail party for him at their home in Saigon, at 6 p.m. on 6 March 1959. At his departure two weeks later, Janse said in a statement to Viêtnam-Presse that he was positive about future collaborations between the United States and Viet Nam in issues concerning archaeology and cultural heritage. Especially because "the rich heritage of Viet Nam is of such a character that it concerns a much larger part of the world, and because the interests

1107. Journal d'Extrême-Orient, 5 March 1959: "Le professeur Janze [sic] souligne la contribution de la France aux recherches archéologique au Vietnam." In the French original: "Parfois un excès de nationalisme objecte à l'idée de voir même des collections d'études établies à l'étranger, mais dans ce domaine il faut essayer à mon avis d'agir dans un esprit d'intérêt mutuel et avant tout mettre l'intérêt scientifique au-dessus des passions humaines et donc momentanées le plan du premier ressortissant au pérenne c'est évidemment dans l'intérêt même du Viêt-Nam de faire mieux connaître et mieux apprécier dans le monde son héritage culturel. Bien entendu il y a plus de visiteurs au musée Guimet qu'en Musée de Saigon."

1108. Hoffman 2008: 32. See also Newsweek, 24 September 1962: "The Gregorys of Saigon".

1109. Brinson Demery 2013:141. 
of science transgress national boundaries". He suggested broad collaborations between Vietnamese institutions and orientalists all over the world, according to the principles already established by UNE SCO. ${ }^{1110}$

From Saigon, Janse travelled to Seoul in South Korea, where he arrived on 25 March 1959, and stayed for two weeks. He lectured at the Korean National Museum on the topic "Vietnam: Crossroads of People and Civilization", and to a full house at Yonsei University. He also made a tour of the country, visited the famous temple site at Kyongju near Taegu, ${ }^{1111}$ and "had the opportunity to see some magnificent monuments and collections that are little known". ${ }^{1112}$ On the night before his departure, he wrote to Renée that he had just had a long chat with the Director of the Asia Foundation about setting up a school for Asian studies, which was followed by

a wonderful lunch at Vietnamese Embassy here. There were the German Ambassador [Richard Hertz], the French Chargé d'Affaires, the rector of the University and his wife, the director of the Nat. Museum and his wife and the Hendersons. It was very pleasant and $\mathrm{Mr}$ and $\mathrm{Mrs}$ Anh send you their very best regards. This was one of the rare occasions you would have liked and we all regretted you were not there. [...] The Hendersons send you their best regards and love. ${ }^{113}$

Gregory Henderson (1922-1988) was a leading Korea scholar and collector of Korean Art at Harvard, and had served with the United States Foreign Service and worked as Vice Consul and Cultural Attaché in Seoul. ${ }^{1114}$ His wife Maia (or Maria-Christine Elisabeth von Magnus Henderson) was born in an aristocratic German family in Berlin. She was as well-respected an art collector as her husband, and later became a well-known

1110.Viêtnam-Presse, 21 March 1959: "Déclaration du Pr Olov R.T. Janse, archéologue americain à son départ de Saigon".

111. Advertisement for Janse's visit to Seoul, not dated. NAA: Janse 2001-29.

1112. Letter from O. Janse to T. Nerman, 12 May 1959. Arbetarrörelsens arkiv och bibliotek. Ture Nerman 3.1.46.

1113. Letter from O. Janse to R. Janse, 2 April 1959. NAA: Janse 2001-29.

1114. Gregory Henderson has written an interesting personal account of Korea in 1950, in Cotton \& Neary 1989:175-182. See also Henderson 1968. 
philanthropist in Harvard. ${ }^{115}$ The Hendersons were in many ways the typical friends of Olov and Renée Janse: well-educated cosmopolitans who mixed art and artefact collection with academic careers and foreign service. Janse's note at the end of his letter indicates that he was not overly enthusiastic about the current social context in Saigon, and moreover it testifies to Renée's importance to the social side of his profession: "This was one of the rare occasions you would have liked and we all regretted you were not there $[\ldots] . "$

Olov returned to the United States via Tokyo, and arrived in Washington, DC, in early May 1959. In July he spoke about Vietnam on the Voice of America radio station, and in the autumn he lectured at Yale University about his experiences from Southeast Asia. His mission in Vietnam was also noted in the US press, and in an interview in The Washington Post, Janse emphasizes the important new finds at the Oc Eo site. Oc Eo is here described as "a city" and "cosmopolitan centre of traders and artisans". It was only now, Janse says, when he was back as a visiting professor in 1958-59 that he saw and understood the importance of the new finds and immediately saw them as confirming his own theories on cultural diffusion through prehistoric connections between Vietnam and the Mediterranean. Having studied Malleret's finds from Oc Eo at the museum in Saigon, he was now convinced that "the [kneeling figurine] sculpture was executed from a Mediterranean-style design by one of the artisans of Oc Eo or another of the many hidden cities which have since been discovered from the air in that vicinity". The end of the article takes a turn towards the present:

The strife-torn post-war years have not only halted work on Oc-Eo, but have stymied attempts to uncover several other city sites also visible from the air. But it is Janse's hope that an international commission - British, American, French, Italian and Japanese - which is planning hydraulic projects in the area can be persuaded to aid in further work under scientific supervision. ${ }^{1116}$

\footnotetext{
1115. Obituary in The Boston Globe, 23 December 2007: "Maria-Christine von Magnus Henderson."

1116. The Washington Post, City Life section (Tony Gieske) 20 July 1959: "Hidden City in Viet-Nam Yields Pre-Christian East-West Ties".
} 
At this time, his mind was occupied with the plans for archaeological and anthropological investigations connected with the massive development programme around the Mekong River: The Mekong Project. Initiated by the United Nations Economic Commission for Asia and the Far East (ECAFE) in 1952, and formalized with the appointment of an international "Mekong Committee" and a "Statute of the Committee for Coordination of Investigations of the Lower Mekong Basin" in 1957, the project sought to establish a basis for economic development by creating irrigation systems, building hydroelectric dams, and in other ways using the water resources provided by "the mother of waters", the mighty Mekong. ${ }^{1117}$ It seemed an excellent opportunity for all parties involved. The governments of the nations along the river, Thailand, Laos, Cambodia, and South Vietnam, saw opportunities for economic uplift, the United Nations saw an occasion to unite international knowledge and science in a project for the betterment of humanity, and the United States (as well as the UN) saw it as a chance to strengthen the more or less fragile non-communist West-friendly governments in all four countries to prevent the further spread of communism over Southeast Asia.

It is possible to draw parallels here between the Mekong Project and the construction of the Aswan High Dam in Egypt in 1960. The Aswan Dam became an arena for international Cold War politics, and the operations known as the Rescue of Nubian Monuments and Sites became a well-known flagship project for UNE SCO. ${ }^{1118}$

Olov Janse and his new friend Bill Solheim also saw the potential of the Mekong Project. If an international effort, similar to those that had already been initiated in the fields of sediment analyses, aerial surveys, river measurements, fish inventories, and cement and construction technology, could be made in the fields of anthropology and archaeology, it could mean a dramatic increase in the cultural and historical knowledge of a major part of mainland Southeast Asia. ${ }^{1119}$ Moreover, they rightly pointed to the importance of understanding the cultural and historical setting for the outcome of the entire project. Here in the words of Bill Solheim and Robert Hackenberg:

In the majority of [similar engineering programs] it has been assumed that everyone is for progress and all that presumably goes

1117. Cosslett \& Cosslett 2013: chapter 4.2.

1118.E.g. Meskell 2018: chapter 2.

1119. Solheim \& Hackenberg 1961:2459-2460; Solheim 2002:8. 
with it. High level planners never stop to think that people in specific areas to be affected by such a program have been living their present way of life for some time and feel emotionally and practically committed to this way of life. [...] The people, their culture and the historic and prehistoric background of their culture, are a major subject for research and understanding if the total program is to be successful. [The] best way to go about this study is through an anthropological-archaeological approach. ${ }^{1120}$

In the article they further emphasize such aspects as the Buddhist tradition of merit-making and the principle of material impermanence, which could easily end up in conflict with the capitalist principle of accumulation of surplus upon which the Mekong Project was built. ${ }^{1121}$ Janse and Solheim spent much time and effort over several years to gain funds and support for their project. On his visits to Washington, DC, Solheim stayed with Olov and Renée "in their very interesting Washington apartment; interesting in the large number of photos from Vietnam and of receptions etc. by or for the King of Sweden, to which [they] were always invited" ${ }^{1122}$ According to Bill Solheim they "received much moral support, but no funds" for their proposed project. ${ }^{1123}$ Janse, on the contrary, writes in a letter to Ture Nerman in August 1961, that they "have succeeded fairly well in raising interest among all interested parties, and the [US] Congress has voted the necessary funds". ${ }^{1124}$ Their efforts would, however, prove to be in vain. Owing to increasing political tensions in Southeast Asia, the Mekong Project would effectively be put on hold in the early 1960 s.

Another major concern for Olov Janse after his return from Asia, was the Art and Archaeology of Vietnam exhibition at the Smithsonian Institution. As a "consultant" to the official organizer Thomas Beggs, Janse played a key role in organizing the exhibition space, selecting the artefacts to be displayed, and writing the exhibition catalogue. ${ }^{1125}$ The personal connections and friendships that had allowed him to act as liaison be-

1120. Solheim \& Hackenberg 1961:2460.

1121. Ibid:2467.

1122. Solheim 2002:8.

1123. Ibid.

1124. Letter from Olov Janse to Ture Nerman, 20 August 1961. Arbetarrörelsens arkiv och bibliotek. Ture Nerman 3.1.46.

1125. Smithsonian Institution 1960. 
tween the US organizers and Vietnamese scholars and diplomats had been reinforced by his recent visit to Saigon. On 1 August 1960 Nghiem Tham, Director of the Vietnamese Monument's Department in Saigon, arrived in Washington along with the collections to be put on display. The exhibition had been previewed at the Dien Hong Palace in Saigon before it was packed and shipped, in 27 packing cases that left Saigon together with Nghiem-Tham at the end of June. When Nghiem Tham arrived with the 27 cases in Washington, DC, he was greeted by Olov Janse. In an interview in The Times of Viet Nam to mark the occasion, Janse says:

The exhibit is important in that it shows that Viet Nam was linked with the Western world some 2,000 years ago, and that Vietnamese culture, far from being a branch of the Chinese, has ties with the Greco-Roman empire and the Christian culture of Asia Minor as well as that of China and Southeast Asia. ${ }^{1126}$

The disconnection from China was a major theme of the exhibition. ${ }^{1127}$ Janse's updated narrative, which emphasized connections with the classical traditions of the Western world, fitted perfectly with the ambitions of the Diem regime. In the words of Matthew Masur, "it constructed a historical narrative of a people fiercely protective of their independence, as evidenced by their millennia of resistance to China. But it also suggested a degree of cultural flexibility - a Vietnamese willingness to adopt the best characteristics of other cultures", ${ }^{1128}$ notably of cultures rooted in the classical Mediterranean. The exhibition pressed all the right buttons in the relationship between Diem's Republic of Vietnam and the United States of America, and as such it served as an important piece of public diplomacy.

The exhibition opened at the Smithsonian's Museum of Natural History on 26 October 1960 , the national day of the Republic of Vietnam. In the entrance hall stood an altar devoted to the cult of ancestors, with incense-burners, candlesticks, votive tablets, parasols, and traditional weapons. Visitors were enveloped by "the soft sounds of Vietnamese music

1126. The Times of Viet Nam, 26 August 1960: "Vietnamese art exhibition slated for Smithsonian in October".

1127. See also a review in The Washington Post, 11 September 1960: "At Smithsonian: Viet Nam Relics Shown" where there is much focus on Oc Eo and the Mediterranean connection.

1128. Masur 2009:302-303. 
and the scent of burning incense". ${ }^{1129}$ One visitor said that he felt as if he was "transported half way around the world in a fraction of seconds". ${ }^{1130}$

In the other ten rooms of the exhibition there was also information of a drier character: a large map of Vietnam, a collection of Vietnamese stamps, two glass cases containing books and pamphlets about Vietnam and photographs representing the country's famous historical and artistic sites. Five rooms were reserved for ancient art objects, such as bronze kettledrums, ceramics, Cham art, and artefacts excavated from Oc Eo. The artefacts in the ancient art section had been borrowed from other collections, most of them excavated by Janse, at museums in Brussels, Harvard, Saigon, and Hué. ${ }^{1131}$ One room contained "common articles" connected to ethnic minority groups, and one displayed objects from Vietnamese traditional music and theatre, including instruments and costumes. Another room showed paintings of contemporary artists, and the last one showed handicraft articles, furniture, jewellery, and clothing. ${ }^{1132}$

Matthew Masur has emphasized the direct influence of the Diem regime on the layout and contents of the exhibition. Some overt political propaganda for Diem was also included, such a poster with Diem's portrait, but that did not go down well with the visitors in Washington, DC. Yet no one complained of the propaganda for a certain West-oriented state formation in Vietnam, that was embedded in the historical narratives and themes of the exhibition. On the contrary, "visitors tended to respond positively to materials $[\ldots]$ described as 'of a cultural nature"'. ${ }_{1133}$

After Washington, the exhibition toured New York, Philadelphia, Cleveland, and Baltimore, and the states of Massachusetts, Missouri, California, and Oregon, before it was packed up and returned to Saigon. It was a great success with more than a hundred thousand visitors, many of them influential, culturally aware, and politically engaged Americans. ${ }^{1134}$

While the exhibition was a success in terms of raising the awareness of Vietnam's history and culture in the United States, and creating a sense of purpose in the relations between them, it was not so much a success

1129. Masur 2009:293.

1130. Masur 2009:293, and sources cited there.

1131. Smithsonian Institution 1960:16; see also letter from J. O. Brew to O. Janse, 13 September 1960. The Peabody Museum archive, XF_41-63_01.

1132. The information about the exhibition layout is taken from an album in Janse's personal archive (NAA: Janse 2001-29).

1133. Masur 2009:308.

1134. Ibid. 


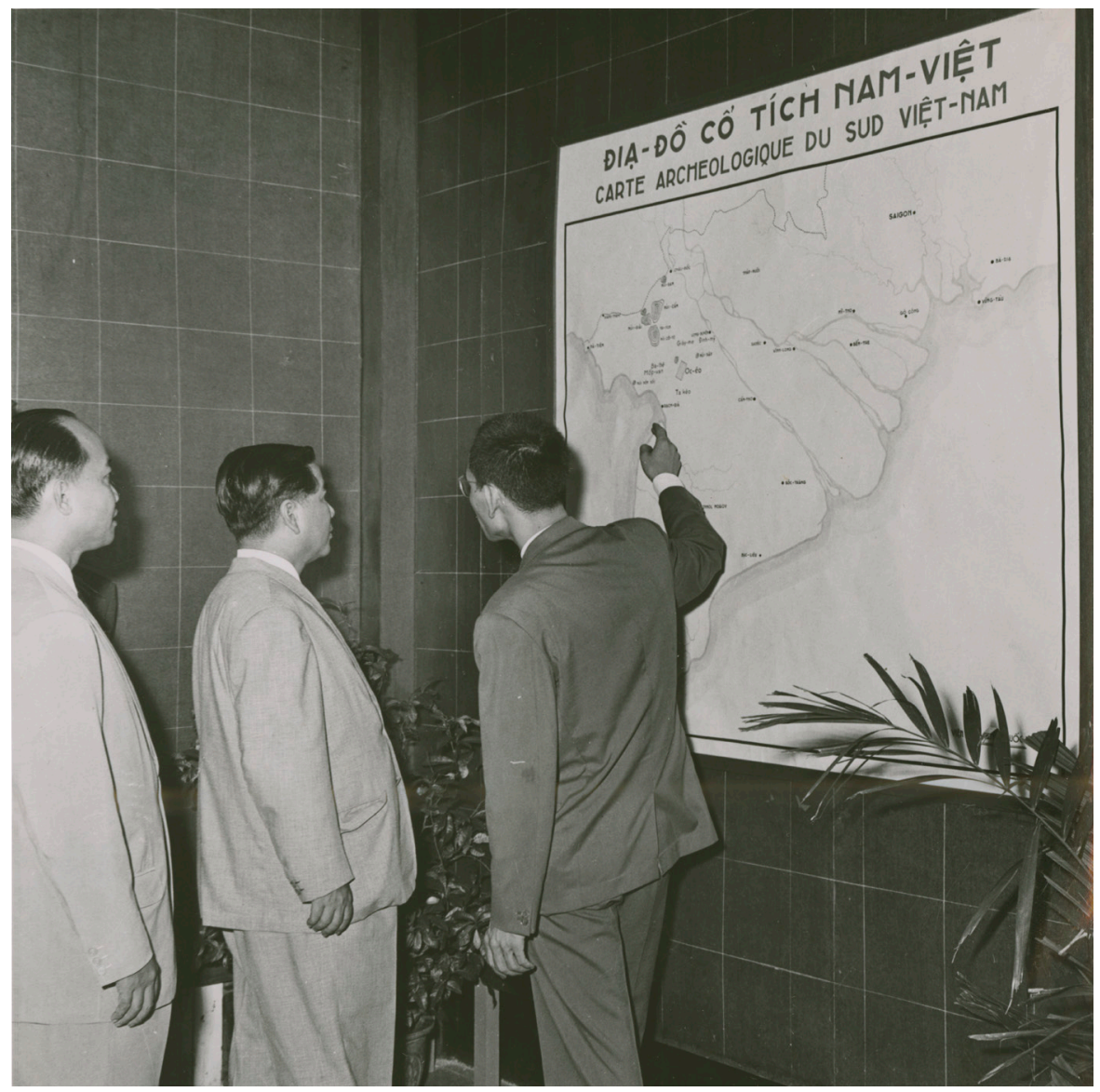

Fig. 80. Dr.

Nghiem Tham shows President Diem the location of Oc Eo, on a map in the room of antiquities at the preview of Art and Archaeology of Vietnam in Saigon 1960.

for Diem personally. The personal propaganda elements had a more negative than positive effect among the American visitors, and moreover, the exhibition coincided with a coup in Vietnam. On 11 November, a mere fortnight after the opening of the exhibition in Washington, a group of military officers launched a coup against Diem in Saigon. It failed, but it indicated some serious problems with Diem's rule in South Vietnam. The situation was indeed fragile. Diem's brother Ngo Dinh Nhu had acquired a very strong position in government affairs, and his wife, Madame Nhu, had gained so much influence that she was sometimes referred to as the First Lady of South Vietnam. All three - the President, his brother and his sister-in-law - lived together in the presidential palace. They led an extravagant lifestyle, and Madame Nhu in particular made lofty, arrogant comments about the Vietnamese people. In combination with Diem's 
repressive style of rule, his religious preferences and open resentment of Buddhism, along with accusations of corruption, the regime was weakened by the day.

In the United States, John F. Kennedy won the presidential election in November 1960 (to Janse's delight) and was inaugurated in January 1961. His Vice President was Lyndon B. Johnson. At about the same time in North Vietnam, Ho Chi Minh and his associates formed the National Liberation Front - NLF - as a new organization to replace the Viet Minh. Among its enemies, the NFL would go under the scornful name Viet Cong - "Communist Traitors to the Vietnamese Nation".

The new leaders of the United States were concerned about the seeming fragility of Diem's regime, but they had no intention of abandoning the campaign against communism. In his inauguration address, John F. Kennedy said: "To those new states whom we welcome to the ranks of the free, we pledge our word that one form of colonial control shall not have passed away merely to be replaced by a far more iron tyranny." ${ }^{1135}$ Despite doubts in President Diem's ability to rule in South Vietnam, the United States got more and more deeply involved in the conflicts that bubbled beneath the surface in Saigon.

In May 1961, Lyndon Johnson made a state visit to India and Southeast Asia during which he met President Diem and Madame Nhu, and famously called President Diem "The Churchill of Asia". Upon his return to Washington, Johnson invited Olov Janse to dinner, with representatives of the states he had visited on his journey, as well as some advisers to President Kennedy. "Very interesting and instructive", says Janse in a letter to Ture Nerman. ${ }^{1136}$

Although Janse was invited to this and other functions at embassies or hosted by US government officials, ${ }^{1137}$ he was never used in any direct advisory role to decision-making politicians or policy-makers, despite the apparent lack of broader experience and more profound cultural knowledge that continued to characterize US involvement in Vietnam.

In the summer of 1961 , Janse received another generous research grant

1135. John F. Kennedy Presidential inauguration address, 20 January 1961.

1136. Letter from O. Janse to T. Nerman, 30 August 1961. Arbetarrörelsens arkiv och bibliotek. Ture Nerman 3.1.46.

1137. Around this time he was also in contact with Senator J. William Fulbright (Letter from Fulbright to Janse, 27 July 1959. NAA: Janse 2001-29) and Supreme Court Justice William O. Douglas (Letter from W. O. Douglas to O. Janse, 25 April 1960. NAA: Janse 2001-29), both with high profiles in the US debates about the Vietnam War. 
of US $\$ 20,800$ from the US Department of State. In September he travelled with Renée by plane to Europe, where they visited London, Paris, Vienna, Athens, Rome, the French Riviera, and Paris again. They stayed in luxury hotels, and he worked on a new book about "the Eurasian cultural complex". ${ }^{113^{8}}$ They returned to Washington, DC, in early November.

Back in the United States, after the Smithsonian exhibition had been shipped back and Janse had returned from his research trip to Europe, he took the initiative to transfer artefacts from his excavated collection at the Peabody Museum, to the National History Museum (formerly Musée Blanchard de la Brosse) in Saigon. The Peabody Museum and Harvard-Yenching Institute approved of the plans, Janse selected the artefacts, and in February 1963 a collection of 150 objects, or "samples", from Janse's original collection from Indochina were dispatched to Saigon. ${ }^{1139}$ An article in The Times of Viet Nam reports on the reception of the collection in Saigon:

Education Secretary Nguyen Quang Trinh and U.S. Ambassador Frederick Nolting jointly presided at a ceremony held yesterday afternoon at the Viet Nam National Museum [in Saigon] to commemorate the transfer to the Museum of samples of archeological findings offered by the Harvard Yenching Institute and the Peabody Museum of Cambridge, Massachusetts. [...] Ambassador Nolting said that the restoration of these samples of archaeological findings contributed to a better understanding between the American and Vietnamese people in both the cultural and economic fields. In his reply, Mr Trinh said that these samples of findings made 30 years ago by Prof. Olov Janse testify to the fact that Viet Nam has its own basic civilization traced back to times immemorial and helps to explode the deep-rooted belief that this civilisation came solely from the Chinese one. ${ }^{1140}$

1138. The book was never completed, and just like the fourth report volume, we have not found any manuscripts for these works.

1139. Detailed list of artefacts in the Peabody Museum Archive, XF_41-63_01. See also Källén \& Hegardt 2014.

1140. The Times of Viet Nam, 22 May 1963: "VN Antiques Returned to National Museum". 
The American Embassy in Saigon was very pleased with the result of the transfer in terms of its public diplomacy value, and the Chargé d'Affaires wrote to the Director of the Peabody Museum John Otis Brew:

There can be no doubt that this demonstration of unselfishness and sincere interest in Viet-Nam will contribute to a better understanding between the United States and Viet-Nam. ${ }^{141}$

Having read the press reports, an amused and apparently embarrassed Glen Baxter at the Harvard-Yenching Institute wrote to John Otis Brew:

You will be interested to know that the objects were returned to Vietnam grâce à la généreuse initiative de MM Brew, Reischauer, and Baxter. On the matter of initiative, I do think dear old Janse might have been mentioned, since he was the one who urged it in the first place. ${ }^{1142}$

In fact, it was not a very costly endeavour for the Peabody Museum and the Harvard-Yenching Institute to let go of Janse's collection. The collection sat rather uneasily in Harvard, where neither the Harvard-Yenching Institute (which lacked physical premises to house artefact collections) nor the Peabody Museum (which had no particular interest in archaeological artefact collections from Asia) had any use for them. Hence everyone involved seemed to agree that the artefact transfer back to Vietnam was a good initiative with positive effects.

Overall, the end of the 1950 s and first years of the 1960 s were a period of great success for Olov Janse. He could harvest the results of personal and professional efforts and endeavours after a long and at times difficult career. In Sweden, his memoirs received glowing reviews, ${ }^{1143}$ and in November 1961 he became a (foreign) member of Vitterhetsakademien, The Royal Swedish Academy of Letters, History and Antiquities. In the

1141. Letter from William C. Trueheart at the American Embassy in Saigon, to John Otis Brew, Director of the Peabody Museum, 24 May 1963. Peabody Museum Archive: XF_41-63_01.

1142. Letter from Glen W. Baxter to John Otis Brew, 23 July 1963. Peabody Museum Archive: XF_41-63_01.

1143.E.g. Review in Svenska Dagbladet, 10 February 1960: by Hanna Rydh, "Ljusmannens gåta"; "Exotisk forntid", review of Ljusmannens gåta, by Wilhelm Holmqvist, Vi no. 49,1959 . 
United States, he was a sought-after lecturer and conversation partner at some of the most important academic and policy-making institutions of the time.

Yet Janse was not quite content. In the years around 1960, his letters have a sense of bitterness that seems to stem from a feeling of exclusion. At the centennial celebrations of the student union at his former high school in Norrköping, he wrote to Ture Nerman and complained that he had not been invited: "I should have been invited to the jubilee, shouldn't I, but they don't give a shi fig about me, as usual." ${ }^{1144}$ Around the same time he got very upset and engaged in the situation of the Swedish archaeologist Hanna Rydh, whom he knew from the years in Paris and Stockholm. She had been a student of Oscar Montelius and the first Swedish woman to earn a doctoral degree in archaeology, and was one of few Swedish archaeologists of Janse's generation who promoted a broad, international comparative perspective like his. In addition to her archaeological work, she was politically engaged with women's issues in Sweden and in international organizations. Among her many important professional endeavours, Rydh had led an archaeological expedition to India in the early 1950 s, and published the report Rang Mahal in 1959. ${ }^{1145}$ In several letters to Birger Nerman, Janse writes about Hanna Rydh, that he wants to contribute to a higher and much-deserved recognition of her work, and has therefore written two reviews of Rang Mahal for international journals. ${ }^{1146}$ Hanna Rydh, in turn, had just written a very sympathetic review of Janse's memoirs for a Swedish newspaper, where the preamble reads: "A Swedish humanities scholar with a career almost entirely outside of his home country, is rare. Olov Janse $[\ldots]$ has earned an international reputation for his archaeological work." ${ }^{1147}$ In one of the letters to Birger Nerman, Janse reveals how his sentiments for Hanna Rydh were entangled with a bitterness over his own marginalized position in Swedish academia: "Based on previous experience, I suppose

1144. Letter from O. Janse to T. Nerman, 10 January 1960. Arbetarrörelsens arkiv och bibliotek. Ture Nerman 3.1.46. In the Swedish original: "Så jag borde väl ha blivit inbjuden till jubileet, men mej ski-struntar de i, som vanligt".

1145. Rydh 1959.

1146.E.g. Janse 1960-1961. Also one similar review in France-Asie in August 1960.

1147. Review in Svenska Dagbladet, 10 February 1960: by Hanna Rydh, "Ljusmannens gåta". In Swedish: "Att en svensk humanist gör en vetenskaplig karriär nästan helt utanför sitt hemland hör till ovanligheten. Olov Janse [...] har vunnit internationell ryktbarhet som arkeolog." 
that [they] don't care much about me, and that my judgement makes no difference. I guess that Hanna Rydh is pretty much a victim of Swedish jealousy." ${ }_{1148}$

Even if the pace was less hectic, Olov continued his work in the first years of the 1960s. Renée worked at the Library of Congress, and Olov, who was now formally retired, spent most of his days there as well, working on his fourth report volume. He made occasional trips to the other university cities on the east coast - Boston (Harvard), New York, and Philadelphia - and he and Renée continued to attend functions at embassies and other political and diplomatic institutions. As late as 1963 , he considered an invitation to return to South Vietnam as adviser to the heritage authorities there, but "the plans [were] still a bit vague". ${ }^{1149}$

In their private life, however, Olov and Renée were slowing down and downsizing. Renée wrote dark poetry, and eventually developed a new blond persona. They were heartbroken by the deaths of their Swedish friend Ernst J. Lundqvist (always called Lunkan) in 1958, their American friends Arthur and Augusta Hartt in 1960 and 1961, and their close, almost-like-family friend Barbro Nerman in 1961. In the end of 1962, shortly after Olov had celebrated his seventieth birthday, they sold the summer cottage at Cove Point and moved to a bigger apartment in the same condominium as before, at 4000 Massachusetts Avenue, overlooking a green city park. Olov writes in a letter to Birger Nerman: "At first country life was pleasant for a change, but it is too much to deal with. We are quite busy here, and with the location of our new apartment we have the pleasures of the countryside combined with the comforts of the city." ${ }_{1150}$

Meanwhile, in Indochina, the situation was spiralling out of con-

1148. Letter from O. Janse to B. Nerman, 10 June 1960. Riksarkivet. Kartong 7. Korrespondens Brev 1957-1961. In the Swedish original: "Att döma av tidigare erfarenheter, har jag på känn att vederbörande inte bryr sig så mycket om mig och att mitt omdöme inte spelar någon roll. Förmodar att Hanna Rydh till stor del är ett offer för den svenska avundsjukan."

1149. Letter from O. Janse to T. Nerman, 5 January 1963. Arbetarrörelsens arkiv och bibliotek. Ture Nerman 3.1.46.

1150. Letter from O. Janse to B. Nerman, 12 July 1962. Riksarkivet. Kartong 8. Korrespondens Brev 1962-1971. In the Swedish original: "I början var det roligt med lantlivet som en omväxling med det blir för mycket att styra med. Dels är vi rätt så upptagna här, dels har vi med läget av vår nuvarande bostad både landets behag med stadens bekvämligheter i förening." 
trol. ${ }^{1151}$ The NLF was fighting against President Diem's Army of the Republic of Viet-Nam (ARVN) to gain full control over Vietnam. John F. Kennedy was at first reluctant to offer support to ARVN with ground troops, but just like his predecessors he was caught in a Cold War logic, which saw Ho Chi Minh and the NLF first and foremost as marionettes in the hands of an international communist conspiracy. The US involvement could thereby be justified as a battle against evil forces, for a better world. Hence Kennedy doubled US funding and material support for ARVN, authorized the use of napalm and Agent Orange, and increased the number of military advisors, who soon (in violation of the Geneva Accords) got involved in direct combat situations. In an interview about the sentiment in the United States at this time, journalist and foreign policy expert Leslie Gelb says:

None of us knew anything about Vietnam. Vietnam in those days was a piece on a chessboard, a strategic chessboard, not a place with a culture and a history, that we would have an impossible time changing, even with the mighty force of the United States. ${ }^{1152}$

In South Vietnam, the people's resentment of President Diem grew as he launched a programme for forced relocation of villages, and his brother Nhu organized ruthless security forces that pursued all who were not loyal to the regime. It has been argued that many people then offered their support to the NLF, not so much because they wanted to live under communist rule, but as a reaction against the unjust treatment by Diem, his family, and his American allies. Ho Chi Minh, who worked conscientiously to gain the trust of people in rural areas, promised to reunite the war-torn country, throw out the foreigners and liberate the people. Towards the end of 1962 , President Kennedy began to realize that the Vietnamese people hated the American involvement in their country, but with a weak Diem by his side he probably saw no other choice but to continue the fight against communism, to keep the trust of his own people and win the next presidential election.

1151. The summarized descriptions of the situation and political events leading up to the war in South Vietnam and the United States refer to Chapman 2013, Logevall 2012, and Tønnesson 2010.

1152. Interview with Leslie Gelb, in The Vietnam War, a television documentary series written by Geoffrey C. Ward, directed by Ken Burns and Lynn Novick. 2017. 
In June 1963, a protest against the repression and persecution of Buddhists by the Catholic Diem regime led to public uproar where the monk Thich Quang Duc set fire to himself at a crossroads in Saigon as an ultimate manifestation of the Buddhist protest. The previous resentment or fear of the Diem regime was for most people turned into disgust or hatred when Madame Nhu made shockingly arrogant comments on television about the violent protest, calling it a "barbecue" and offering to provide matches if they wanted to do it again. On 1 November 1963, a group of ARVN generals launched a coup (neither supported nor combatted by the United States) against President Diem, which ended in the brutal assassination of both Diem and Nhu. Madame Nhu, who was on a PR trip to the United States, was the only one who escaped.

The coup and the assassination of President Diem sent shock waves through the United States administration, but the situation was almost immediately overshadowed by the assassination of President Kennedy in Dallas three weeks later, on 22 November 1963.

\section{The end}

Something happened at this point in Olov's and Renée's lives. It might have been the cumulative effect of a series of events - we can only speculate. The situation in Vietnam, where their fundamental understanding of the Vietnamese people as gratefully Western-friendly was completely shattered, and on top of that the assassinations of both Diem and Kennedy, must have been incredibly difficult to process and accept, especially for Olov who had been so closely involved with the governments of both countries. We know from Renée's poetry and notes in her archive that she suffered some kind of depression in autumn 1963 and early 1964. We notice at the same time a break in Olov's otherwise regular correspondence with Ture and Birger Nerman between January 1963 and June 1964. In the first letter after the break, he has a slightly different, less distinct hand, when he writes that he is sorry that he hasn't been able to write for a long time, because he has been quite unwell during the winter. Having worked too much, he says, he has been out of gear and has suffered from some kind of heart condition. ${ }^{153}$ Yet his language is changed too - not anglicized, but rather with uncharacteristic disruptions, spelling mistakes

1153. Letter from O. Janse to B. Nerman, 12 June 1964. Riksarkivet. Kartong 8. Korrespondens Brev 1962-1971. 
and inconsistencies suggesting that he might have suffered from a stroke or some neurological ailment.

The break around 1963-64 also put a definite end to Olov Janse's academic career. The fourth report volume was never completed, the book on "the Eurasian cultural complex" was never mentioned again, and the few texts and notes that remain from the last two decades of his life seem to confirm that something happened around 1964 that affected his brain and his capacity for academic analysis. In the following years he returned to his research from the early twentieth century, examining bracteates and similar issues, but without any real focus. His last writings are theories about prehistoric drugs and mushrooms, secret societies, gnosticism, astrology and mysterious numerical series scribbled on loose pieces of paper. ${ }^{1154}$

Despite this apparent decline, Olov and Renée continued to be regular guests at functions at the embassies of Sweden, France, Morocco, Tunisia, Vietnam, Iceland, Laos, Senegal, Latvia, and Lithuania. They also travelled a lot. They visited Sweden twice, in 1964 and 1968, and they went on frequent holidays to Florida - "The Venice of the United States", and to more exotic destinations such as Mexico and the Virgin Islands. Birger Nerman came to visit them in Washington, DC, in 1965, and Olov kept corresponding with Ture Nerman on political developments around the world. More than anything they were upset about student demonstrations, and anti-American protests against the war in Vietnam. Ture Nerman, who had devoted his intellectual life and professional career to political protests, was particularly upset and called the demonstrating students "små snorungar" "som inte begriper något av historien" - "little brats" "who are ignorant about history". ${ }^{1155}$

The correspondence with Ture and Birger Nerman ended in the late 1960s. Ture died in October 1969, and Birger two years later, in August 1971. Olov then disappears from our radar, but he continued his retired life with Renée in their apartment at 4000 Massachusetts Avenue until he died, 92 years old, on 6 March $1985 .{ }^{1156}$ In their archive remains a note, in Renée's shaky hand:

1154. These documents are stored at Antikvarisk-Topografiska Arkivet in Stockholm. Enskilda Arkiv. 59 Olov Janse.

1155. Letter from T. Nerman to O. Janse, 12 December 1966. Arbetarrörelsens arkiv och bibliotek. Ture Nerman 3.1.46. See also Nerman 1967.

1156. Svenska Dagbladet, 28 March 1985: "Obituary" by Margit Althin. 
Fig. 81. The note.

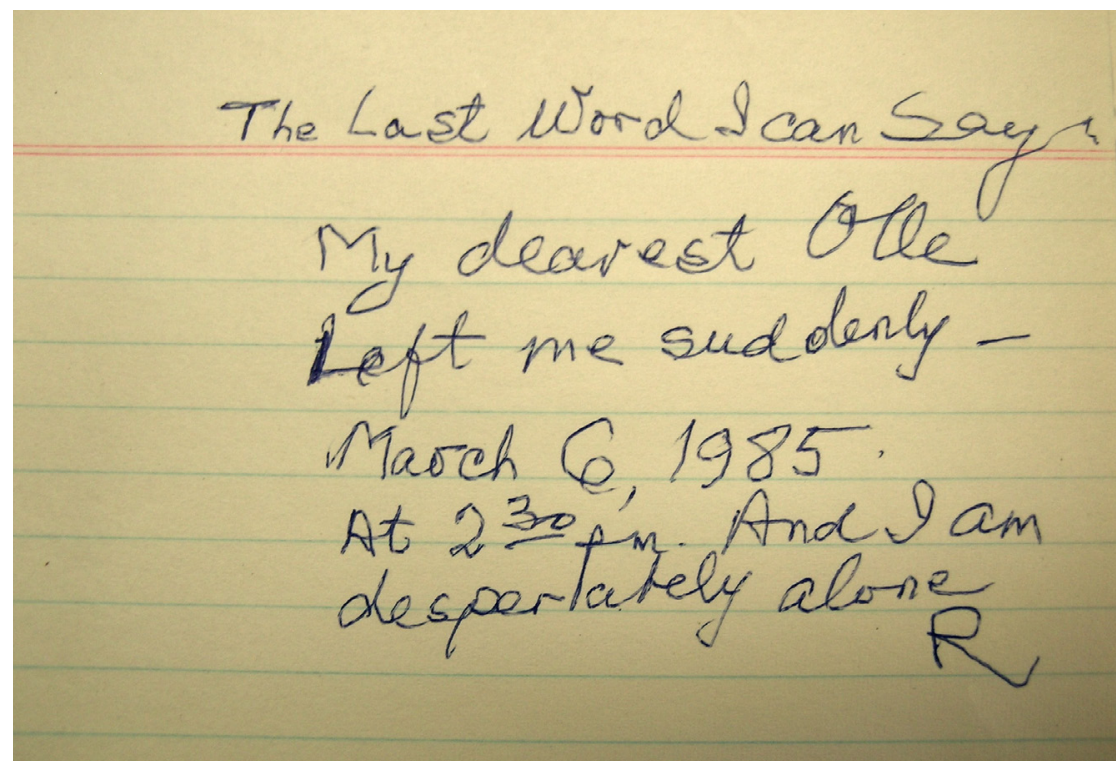

What can be learnt from Olov Janse's years in US government service? In a formal, official sense, he was not particularly important. With very few exceptions, he has not even been noticed by historians of the OSS and Cold War years. Moreover, it does not seem as if he ever thought of himself as an actor of importance in the political processes that led to the Vietnam War. In some sense, he was a lost opportunity. Regarded as one of very few Americans with profound knowledge and insights into the cultures of Indochina, urban and rural, he was not considered for any central advisory role, in a situation that has been criticized in hindsight, particularly for the lack of knowledge about Vietnamese culture among the US administration. This absurd situation can probably best be explained by the blind focus on the Soviet Union among the entire administration, Janse included.

His informal influence can only be speculated about, though he wrote several information texts for administrative purposes, particularly during his time with the OSS and Department of State, ${ }^{1157}$ and he did indeed

1157. These texts were read by key actors in the US administration, for instance Justice William O. Douglas at the US Supreme Court, who wrote a letter to Janse on 25 April 1960, with questions concerning Janse's "War Background Studies" text on Indochina. We know also that Janse sent some of these texts and his archaeological reports to Vice 
meet and mingle with some of the most influential actors in the political administration at the time, both Vietnamese and American. Moreover, he was respected for his knowledge and experience of Indochina. So we can assume that some of his views on Vietnamese culture and history were absorbed and adopted by members of the political administration in Washington, DC.

In connection with his Smith-Mundt-Act-supported visit to Saigon and Korea, and the important exhibition at the Smithsonian Institution which coincided with a crucial moment in the relations between the United States and Diem's regime in South Vietnam, Janse contributed a foundational historical narrative focused on independent resistance against China and fundamental influences from Ancient Greece, which fitted perfectly with the political ambitions of both governments. It took a little tweak, but no major revision of his previous interpretations of the finds from his expeditions to Indochina, to create this new narrative. Yet while he was open to some tweaking in order to rule China out of the picture, Janse stayed true to his comparative archaeological perspective with diffusionism as the main explanatory model. He also kept his devoted love for France and the French colonial system, despite all the inconveniences it must have brought.

In conclusion, Olov Janse lent himself to US government service, and thereby altered some of his perspectives and results. At the same time, though, he kept most of his passions intact. Some were convenient in the US setting, such as his aversion and fear of the Soviet Union, and the notion of necessary mental development from primitive natives (in Indochina) to culturally-accomplished Western citizens (in the new Republic of Vietnam). Others were not so convenient, for instance his love for France and his steadfast belief in French colonialism. In other words, he was neither entirely adaptable nor entirely rigid. Rather, he was both flexible and resilient - flexible enough to adapt to the new situation, but largely resilient and loyal to his former principles and passions, even when they did not offer him any immediate benefits.

The sad irony is that the part of Janse's knowledge and experience of Indochina that could potentially have contributed the most to US policy making was never considered important. We see a glimpse of it in the article about the Mekong Valley Project, where a deeper understanding

President Richard Nixon in 1954 and Senator J.William Fulbright in 1959. NAA: Janse 2001-29. 
of the discourses of rural Indochina (Buddhist, animist, native administration...) is brought up as a major factor to consider for a successful outcome of the river development project. ${ }^{1158}$ Indeed in his colonialperiod expeditions, Janse had already taken an interest in the cultural logic behind the actions of rural communities in Indochina. He wrote about such issues at length in his memoirs ${ }^{1159}$ and in parts of the texts he produced for the OSS and the US Department of State. ${ }^{160}$ It was exactly this kind of interest in the cultures of Vietnam that was missing from the "strategic chess play" in the US administration leading to the Vietnam War. For Olov Janse too, such interests were overshadowed by his own fear of the Soviet Union, and his staunch belief in the French mission civilisatrice.

1158. Solheim \& Hackenberg 1961.

1159. Janse 1959.

1160. See the chapter "OSS and the US Department of State". 